OPEN ACCESS

Edited by:

Ioannis Tokatlidis,

Democritus University of Thrace,

Greece

Reviewed by:

Fokion Papathanasiou,

University of Western Macedonia,

Greece

loannis Mylonas,

Hellenic Agricultural Organization -

ELGO, Greece

*Correspondence: Athanasios L. Tsivelikas

A.Tsivelikas@cgiar.org

Specialty section This article was submitted to Crop and Product Physiology, a section of the journal

Frontiers in Plant Science

Received: 17 December 2021

Accepted: 24 January 2022

Published: 18 February 2022

Citation:

Tsivelikas AL, Ben Ghanem H, El-Baouchi A and Kehel Z (2022) Single-Plant Selection at Ultra-Low Density Enhances Buffering Capacity

of Barley Varieties and Landraces to Unpredictable Environments and Improves Their Agronomic

Performance.

Front. Plant Sci. 13:838536 doi: 10.3389/fpls.2022.838536

\section{Single-Plant Selection at Ultra-Low Density Enhances Buffering Capacity of Barley Varieties and Landraces to Unpredictable Environments and Improves Their Agronomic Performance}

\author{
Athanasios L. Tsivelikas ${ }^{1 *}$, Hajer Ben Ghanem², Adil El-Baouchi ${ }^{3}$ and Zakaria Kehel1 \\ ' Genetic Resources Section, International Center for Agricultural Research in the Dry Areas (ICARDA), Rabat, Morocco, \\ ${ }^{2}$ Field Crop Laboratory, National Institute of Agricultural Research, University of Carthage, Tunis, Tunisia, ${ }^{3}$ African Integrated \\ Plant and Soil Research Group (AiPlaS), AgroBioSciences, Mohammed VI Polytechnic University, Ben Guerir, Morocco
}

Rainfall and temperature are unpredictable factors in Mediterranean environments that result in irregular environmental conditions for crop growth, thus being a critical source of uncertainty for farmers. This study applied divergent single-plant selection for high and low yield within five barley varieties and two Tunisian landraces under semi-arid conditions at an ultra-low density of 1.2 plants $/ \mathrm{m}^{2}$ for two consecutive years. Progeny evaluation under dense stands following farmers' practices was conducted in two semi-arid locations in Tunisia during one cropping season and in one location during a second season, totalling three environments. The results revealed significant genotypic effects for all recorded agronomic and physiological traits. No genotype $\times$ environment interaction was shown for biological yield, implying a biomass buffering capacity for selected lines under different environmental conditions. However, genotype $\times$ environment interaction was present in terms of grain yield since plasticity for biomass production under drought stress conditions was not translated directly to yield compensation for some of the lines. Nevertheless, several lines selected for high yield were identified to surpass their source material and best checks in each environment, while one line (IH4-4) outperformed consistently by $62.99 \%$ on average, in terms of grain yield, the best check across all environments. In addition, improved agronomic performance under drought conditions induced an indirect effect on some grain quality traits. Most of the lines selected for high yield maintained or even improved their grain protein content in comparison to their source material (average increase by $2.33 \%)$. On the other hand, most of the lines selected for low yield indicated a poor agronomic performance, further confirming the coherence between selection under ultra-low density and performance under dense stand.

Keywords: barley, buffering capacity, drought conditions, single-plant selection, ultra-low density, yield compensation 


\section{INTRODUCTION}

On a global scale, barley (Hordeum vulgare L. subsp. vulgare) ranks fourth among cereals in terms of production quantity, after wheat, maize, and rice, providing nutrient benefits for both livestock and humans (Newton et al., 2011; FAOSTAT, 2021). Barley is a member of the grass family (Poaceae). It is a versatile crop with the ability to adapt to unfavourable conditions that distinguish it as one of the best models and most suited crops for studying adaptation to climate change (Dawson et al., 2015). Despite its resilient nature to climate disruptions, high relative yield gap rates have been estimated for barley crop, ranging between 12 and $75 \%$ for the rainfed systems in Europe (Schils et al., 2018) and up to $25 \%$ for the rainfed barley fields in Alberta, Canada (Chapagain and Good, 2015). Volatile climate conditions, management practices, genetic factors, as well as social restrictions on the use of inputs and economic disincentives to intensify crop production are amongst the main causes of considerable variation and stagnated or even declined yields for barley and other major crops (Peltonen-Sainio et al., 2009; Lin and Huybers, 2012; Mueller et al., 2012; Tokatlidis, 2014; Ray et al., 2015; Hochman and Horan, 2018).

In this regard, climate change seems to induce severe yield losses for barley crops mainly due to an increase in maximum temperature during the grain filling period causing heat stress, as well as due to an increased frequency of drought events during the stem elongation period (Brisson et al., 2010; Bento et al., 2021). Climate change impacts and, hence, their consequences do not follow an evenly distributed spatial pattern with their magnitude varying from region to region (Trenberth, 2011). Among the most fragile areas, the Mediterranean region has been well recognised as a prominent climate change hot spot (Diffenbaugh and Giorgi, 2012; Alessandri et al., 2014). Mediterranean environments are characterised by high inter-annual variability of temperature and rainfall patterns, increasing the uncertainty of maintaining production at higher levels (Cammarano et al., 2019). This unforeseen variation is likely to affect yield and yield quality directly, due to impact on crop physiology and indirectly, due to alterations in nutrient mineralisation and availability for crops (Henson, 2011; Cammarano et al., 2019).

However, the resource-limited regime in crop stands results in plant-to-plant competition due to the concurrent demand of individual plants for the available resources (Weiner and Damgaard, 2006). As highlighted by Farrior et al. (2013), resource limitation creates incentives for plants to over-invest in resource capture at levels that are suboptimal for the productivity of a plant in isolation but pay off for the plant interference with the others, such as investment in height growth for light capture or in fine roots for belowground resources. Competition between individuals within a crop may lead to developmental dissimilarities and intra-crop inequality (Weiner and Damgaard, 2006; Tokatlidis, 2017). This intra-crop inequality, in turn, further aggravates the unequal share of limited resources, thus intensifying inter-plant competition, functioning as a vicious circle between plant asymmetry and competition that perpetuates all along the crop cycle. Evidently, this condition affects plant growth detrimentally to crop yield performance (Pan et al., 2003; Pagano and Maddonni, 2007). Complexity is exacerbated under high stand densities since plants are more prone to early established inequalities leading to pronounced morphological and physiological differences which in turn affect resource use efficiency during critical developmental stages of the crop (Tollenaar et al., 2006; Rossini et al., 2011; Yan et al., 2017; Sher et al., 2018).

Planting density is one of the key factors in achieving crop uniformity by minimising interplant competition and ensuring an equal share of resources, eventually attaining maximum profitability. Recommending an optimum planting density is not an easy task, since the relationship between planting density and grain yield is governed by several parameters that fall under the genotype, environment, and crop management effect (Assefa et al., 2016, 2018; Carciochi et al., 2019; Bastos et al., 2020). In wheat, for example, Bastos et al. (2020) concluded that for high yielding environments and less limited resources the number of plants required to maximise yields was very low and below any commercially recommended number of plants for this crop, while for low yielding environments a higher density was needed to sustain maximum yields. Likewise, according to Matsuyama and Ookawa (2020), a lower seeding rate than the one commonly practiced in Japan was more suitable in achieving high yields and improved lodging resistance for those wheat cultivars that were characterised by a high number of grains per spike when these cultivars were planted in soils with abundant resources. In barley, most of the research concludes that a seeding rate which establishes between 300 and 360 plants $\mathrm{m}^{-2}$ is usually the optimal one (Thomason et al., 2009; O’Donovan et al., 2012; Perrott et al., 2018). However, the recommended density can vary considerably depending on the field properties and climate conditions or even on the interaction with the genotype (Jedel and Helm, 1995; O'Donovan et al., 2012; Bekele et al., 2020). Undoubtedly, the main constraint to define optimum plant density lies on the large environmental variability that occurs in a particular zone across seasons, as well as on the unpredictability of the inter-annual variation in terms of weather conditions, and predominantly in the amount and distribution of atmospheric precipitations in the rain-fed cropping systems (Tokatlidis, 2014). Therefore, Tokatlidis (2017), highlights the importance of breeding to target varieties that are characterised by homeostasis, that is the ability to withstand external forces that induce acquired plantto-plant inequality and concomitant intra-crop competition, as well as by density-independence, to perform satisfactorily at relatively low densities.

Since intra-crop inequality and inter-plant competition are related to high densities, a condition for selection under ultra-low density that excludes plant-to-plant interference for resources (i.e., nil-competition) is a prerequisite. Such a condition exploits the honeycomb breeding model (Fasoulas, 1988, 1993). Owing to their systematic entry arrangement, locating each plant in the centre of a circular replicate/ring to ensure increased local control and allocating the plants of each entry in a moving triangular grid spread across the whole field for an effective sampling of soil heterogeneity, honeycomb designs objectively 
evaluate sister-lines and apply single-plant selection under a pattern of ultra-low planting density (Fasoulas and Fasoula, 1995). The nil-competition regime maximises the phenotypic expression of genetic differences among individuals, facilitating, further, the detection of desirable genotypes (Kyriakou and Fasoulas, 1985; Fasoula and Fasoula, 2002; Tokatlidis et al., 2010). Moreover, the selection under ultra-low density erases the confounding effects of competition on the identification of high yielding genotypes, induced by the negative relationship between yielding and competitive ability (Kyriakou and Fasoulas, 1985; Chatzoglou and Tokatlidis, 2012; Ninou et al., 2014), while attaining greater heritability by minimising the acquired variance arising from non-genetic sources (Fasoula and Fasoula, 2002; Tokatlidis, 2015). The computation of mathematical parameters that account for relative plant yield efficiency and stability of performance is easily performed and can be applied from the early stages of selection for selecting superior plants, thus reducing the time frame required for the release of improved varieties.

Considering the challenges imposed by climate variation and volatility and the need to expand the range of optimum planting density in field crops, the development of barley cultivars with an innate buffering capacity to perform well enough under varying and unpredictable climate conditions and making optimum use of the available resources, sound as a prudent approach to reduce the gap between actual and attainable yield in barley crop. Hence, the objective of the present study was to investigate the performance and buffering capacity of barley lines under favourable and drought stress conditions in Tunisia. These lines were derived from three commercially released cultivars and two Tunisian landraces, using single-plant selection at ultralow density. Furthermore, the potential to exploit latent or de novo variation within barley cultivars for the development of high-yielding lines with elevated homeostasis and competent qualitative traits is discussed.

\section{MATERIALS AND METHODS}

\section{Plant Material}

To obtain the barley lines evaluated in this study, selection started in 2014 cropping season among five commercially released cultivars in Tunisia (Imen, Kounouz, Lemsi, Manel, and Rihane) and two Tunisian landraces (Ardhaoui and Djebali) planted under the ultra-low density of 1.2 plants $/ \mathrm{m}^{2}$ according to an R-7 honeycomb field layout (Fasoulas and Fasoula, 1995). The selection between entries was based on the computation for each of the entries of the three parameters described by Fasoula and Fasoula (2000), that is (i) the entry's mean $(\bar{x})$, (ii) the entry's standardised mean $(\bar{x} / s)$, and (iii) the entry's standardised selection differential $\left(\frac{\bar{x}_{s e l}-\bar{x}}{s}\right)$. Then, divergent single-plant selection for high and low yield within the top entries was applied by the moving-circle procedure (Fasoulas and Fasoula, 1995) to form the first cycle selected lines. These lines along with the best commercial checks of the region were further subjected to selection in the following cropping season, by applying the same principles of single-plant selection for high and low yield under an ultra-low-density regime of 1.2 plants $/ \mathrm{m}^{2}$ according to an R-21 honeycomb field layout (Fasoulas and Fasoula, 1995). In both years, the selected high-yielding plants were the ones that showed the highest grain weight compared with the mean of the 36 surrounding plants (i.e., 0.027 selection pressure). Low-yielding individuals were identified using the same selection pressure, but in this case, selected plants should weigh at least $10 \mathrm{~g}$ of grains and then bulked according to the source material, to get enough seeds for the next selection cycle and for further evaluation. The whole procedure resulted in 12 first cycle lines ( 8 high yielding and 4 low yielding) and 38 second cycle lines ( 30 high yielding and 8 low yielding) to be assessed in the next seasons' dense stand trials. The honeycomb experimental field layouts and the selection procedure applied for two consecutive years are described in detail by Ben Ghanem et al. (2018). A summary of the selection history of the progeny lines is given in Table 1.

\section{Field Evaluation Trials}

In the 2016 growing season, the 50 first and second cycle selected lines along with five checks (source seed lots of Imen, Ardhaoui, Djebali, Manel, and Rihane) were planted as dense stand field trials at the National Agricultural Research Institute of Tunisia (INRAT) experimental stations in El Kef ( $36^{\circ} 14^{\prime} \mathrm{N}$; $\left.8^{\circ} 27^{\prime} \mathrm{E} ; 518 \mathrm{~m}\right)$ and Mornag $\left(36^{\circ} 37^{\prime} \mathrm{N} ; 10^{\circ} 17^{\prime} \mathrm{E} ; 54 \mathrm{~m}\right)$ in Tunisia. These materials were also planted as dense stand trial the following growing season at Mornag experimental station. The two research stations represent two distinct production environments for Tunisia. Mornag is characterised by clay soil and average annual precipitation of $450 \mathrm{~mm}$. El Kef is

TABLE 1 | Selection history of the single-plant progeny lines derived through divergent selection at ultra-low density and evaluated at the dense stand trials (modified by Ben Ghanem et al., 2018).

\begin{tabular}{|c|c|c|c|c|}
\hline $\begin{array}{l}\text { Source } \\
\text { material }\end{array}$ & $\begin{array}{l}\text { First cycle } \\
\text { HY lines }\end{array}$ & $\begin{array}{l}\text { First cycle } \\
\text { LY lines }\end{array}$ & $\begin{array}{c}\text { Second cycle } \\
\text { HY lines }\end{array}$ & $\begin{array}{l}\text { Second cycle } \\
\text { LY lines }\end{array}$ \\
\hline Ardhaoui & $\mathrm{AH}, \mathrm{AH} 10$ & ALO & $\begin{array}{l}\mathrm{AH} 9-\mathrm{H} 1, \mathrm{AH} 9-\mathrm{H} 2 \\
\mathrm{AH}-\mathrm{H} 3, \mathrm{AH} 10-\mathrm{H} 1 \\
\mathrm{AH} 10-\mathrm{H} 2, \mathrm{AH} 10-\mathrm{H} 3\end{array}$ & $\begin{array}{l}\text { AH9-LO, } \\
\mathrm{AH} 10-\mathrm{LO}\end{array}$ \\
\hline Imen & $\mathrm{H}_{4}, \mathrm{H} 16, \mathrm{H} 17$ & ILO & $\begin{array}{c}\mathrm{H} 4-\mathrm{H} 1, \mathrm{IH} 4-\mathrm{H} 2, \mathrm{IH} 4-\mathrm{H} 3, \\
\mathrm{IH} 4-\mathrm{H} 4, \mathrm{IH} 16-\mathrm{H} 1, \mathrm{H} 16-\mathrm{H} 2, \\
\mathrm{H} 16-\mathrm{H} 3, \mathrm{H} 17-\mathrm{H} 1, \\
\mathrm{H} 17-\mathrm{H} 2, \mathrm{IH} 17-\mathrm{H} 3, \mathrm{IH} 5-\mathrm{VS}\end{array}$ & $\begin{array}{l}\text { IH4-LO, } \\
\text { IH16-LO, } \\
\text { IH17-LO }\end{array}$ \\
\hline Djebali & $\mathrm{DH} 2, \mathrm{DH} 12$ & DLO & $\begin{array}{c}\mathrm{DH} 2-\mathrm{H} 1, \mathrm{DH} 2-\mathrm{H} 2, \\
\mathrm{DH} 2-\mathrm{H} 3, \mathrm{DH} 2-\mathrm{H} 4, \\
\mathrm{DH} 2-\mathrm{H} 5, \mathrm{DH} 12-\mathrm{H} 1, \\
\mathrm{DH} 12-\mathrm{H} 2, \mathrm{DH} 12-\mathrm{H} 3, \\
\mathrm{DH} 14-\mathrm{VS}\end{array}$ & $\begin{array}{l}\text { DH2-LO, } \\
\text { DH12-LO }\end{array}$ \\
\hline Manel & $\mathrm{MH} 18$ & MLO & $\begin{array}{c}\mathrm{MH} 18-\mathrm{H} 1, \mathrm{MH} 18-\mathrm{H} 2 \\
\mathrm{MH} 18-\mathrm{H} 3\end{array}$ & MH18-L0 \\
\hline Rihane & - & - & RH8-VS & - \\
\hline
\end{tabular}

The coding of lines is based on two letters and the number of the selected plant. In the case of the bulk sample, this is indicated with 0 . The first letter indicates the source material from which the line has been selected (A stands for Ardhaoui, I for Imen, D for Djebali, M for Manel, and R for Rihane). The second letter indicates whether the selection is based on high yield $(H)$ or low yield $(\mathrm{L})$. Cases indicated with VS, stand for visual selection. 
TABLE 2 | Monthly precipitation at the two experimental sites for the growing seasons of selection and evaluation trials.

\begin{tabular}{|c|c|c|c|c|c|c|c|c|c|c|c|c|c|c|c|}
\hline Site & Growing season & Trial type & September & October & November & December & January & February & March & April & May & June & July & August & Total \\
\hline El Kef & $13 / 14$ & Selection & 52 & 25 & 103 & 52 & 52 & 35 & 81 & 8 & 53 & 17 & 0 & 1 & 479 \\
\hline El Kef & $14 / 15$ & Selection & 20 & 35 & 43 & 74 & 70 & 66 & 66 & 0 & 22 & 2 & 5 & 46 & 449 \\
\hline El Kef & $15 / 16$ & Evaluation & 18 & 26 & 48 & 5 & 55 & 13 & 89 & 30 & 32 & 5 & 0 & 2 & 325 \\
\hline Mornag & $15 / 16$ & Evaluation & 6 & 57 & 44 & 23 & 18 & 40 & 63 & 14 & 25 & 0 & 0 & 5 & 295 \\
\hline Mornag & $16 / 17$ & Evaluation & 80 & 33 & 77 & 140 & 53 & 36 & 4 & 16 & 0 & 19 & 0 & 0 & 458 \\
\hline
\end{tabular}

characterised by clay loam soil and average annual precipitation of $452 \mathrm{~mm}$ with barley being the most common rainfed crop of the region. The monthly precipitation at the two experimental sites for the growing seasons during which the selection and evaluation trials were held is given in Table 2 .

A non-replicated augmented design field trial was established in all cases, with five incomplete blocks and 15 entries per block. Plots were composed of four rows of $2.5 \mathrm{~m}$ long, each with $0.25 \mathrm{~m}$ spacing between rows, occupying a plot area of $2.5 \mathrm{~m}^{2}$. Plot by plot distance within the same alleyway was $0.75 \mathrm{~m}$ and between alleyways $1.5 \mathrm{~m}$. All trials were planted under a uniform seed rate of 360 seeds $/ \mathrm{m}^{2}$. To ensure the robust establishment of field plots, seeds were treated before planting with Celest top [Diféconazole $(25 \mathrm{~g} / \mathrm{L})+$ Fludioxonil $(25 \mathrm{~g} / \mathrm{L})+$ Thiamethoxam $(262.5 \mathrm{~g} / \mathrm{L})]$ at a rate of $200 \mathrm{ml} / \mathrm{hl}$ of seeds. Basic fertiliser in the form of diammonium phosphate (18-46-0) was applied before planting at a rate of $100 \mathrm{~kg} / \mathrm{ha}$. Complete weed control was attained by chemical applications (Axial: pinoxaden $(100 \mathrm{~g} / \mathrm{L})+$ cloquintocet-methyl $(25 \mathrm{~g} / \mathrm{L})$ at a dose of $1 \mathrm{~L} /$ ha for the narrow leaf weeds and Zoom: dicamba $(66 \%)+$ Triasulfuron (4\%) at a dose of $180 \mathrm{~g} / \mathrm{ha}$ for the broadleaf weeds) and hand weeding. Two spring foliar spray applications of Ogam [Kresoxim-methyl $(125 \mathrm{~g} / \mathrm{L})+$ Epoxiconazole $(125 \mathrm{~g} / \mathrm{L})]$ at a rate of $0.7 \mathrm{~L} / \mathrm{ha}$ were applied as a preventive measure to minimise yield reductions due to fungal diseases. The harvest took place beginning of June, and all four rows per plot were harvested.

\section{Data Records for Agronomic and Physiological Traits}

Several agronomic and physiological traits were recorded across the three environments. Regarding agronomic traits, biological yield (BY: t/ha) and grain yield (GY: t/ha) per plot were measured at maturity and, harvest index (HI) was derived as the quotient between grain and biological yield. Plant height $(\mathrm{PH})$ was measured at maturity from five randomly selected plants within each plot and recorded as the distance in centimetres from soil level to the tip of spikes excluding the awns. Spike length (SL) was recorded as the average of ten representative spikes of each plot from the base up to the tip of the spike. Each of these spikes was then threshed individually and the average grain weight per spike (SGW) expressed in $\mathrm{g}$ for each of the entries was also recorded. Powdery mildew (PM) reaction was scored based on the prevalence of the disease at the seedling stage at El Kef and Mornag stations during the 2016 cropping season based on a disease severity scale from 1 to 5 , with 1 as no symptoms and 5 as highly susceptible.
For physiological parameters, measurements were performed only in the 2016 growing season in the two locations where the trials had been planted. Soil Plant Analysis Development (SPAD) values at the heading stage SPAD were measured on fully expanded flag leaves of three representative plants of each plot using a MINOLTA SPAD 502 Plus chlorophyll meter. Leaf canopy temperature (LCT) was recorded as the average of five representative positions within each plot using an infrared scantemp 440 thermometer. Chlorophyll fluorescence $\mathrm{F}_{0}, \mathrm{~F}_{\mathrm{m}}$, and $\mathrm{F}_{\mathrm{V}}$ parameters were measured at heading time at the fully expanded flag leaves of the three representative plants within each plot, for which the SPAD values were also taken, using an OPTI-SCIENCE 0530 + handheld portable fluorometer. These measurements were then used to calculate the ratios $\mathrm{F}_{\mathrm{V}} / \mathrm{F}_{\mathrm{m}}$ and $\mathrm{F}_{\mathrm{V}} / \mathrm{F}_{\mathrm{o}}$ and thus, test for differences in the activity of photosystem II (PSII).

\section{Grain Quality Parameters}

Representative grain samples from all field plots of the two locations planted in the 2016 cropping season were transferred and evaluated in International Center for Agricultural Research in the Dry Areas (ICARDA) Quality Laboratory. In particular, grain colour, morphology, physiochemical parameters, and $\beta$-Glucans content were assessed.

\section{Grain Morphology and Grain Colour}

Random samples of 70 grains were received from all seed lots representing each plot at the field and scanned using a flatbed scanner (CanoScan LiDE 220; Canon). The images collected were analysed using Grainscan software (Whan et al., 2014), which generated the morphological and colour profile for every single grain. Grain morphology traits, such as perimeter in mm (PRM), grain length in $\mathrm{mm}$ (LNG), and width in $\mathrm{mm}$ (WDT) were calculated for each sample as means of the 70 seeds. In addition, a colour channel intensity output similar to the standardised CIELAB colour space produced by the software (Whan et al., 2014). The GrainScan colours (ColCha1, ColCha2, and ColCha3) were therefore considered proxies for L, a, and b, respectively, representing the lightness of the colour, green or magenta, and blue or yellow.

\section{Physiochemical Parameters}

Barley protein content (PRT) and starch (STRCH) were determined using near-infrared spectroscopy (NIR, Infratec 1241 , Foss). To determine the $\beta$-glucan content ( $\beta$-GLC) the calcofluor-fluorimetric method using a flow analyser (SKALAR $\operatorname{san}^{++}$) was employed. Before this determination, 
TABLE 3 | Genotypic and environmental effects and their interaction on the agronomic traits of barley lines selected under ultra-low density when evaluated under dense stand trials in different environments in Tunisia.

\begin{tabular}{lccccc}
\hline A. Traits recorded in three environments & & & \\
\hline Source of variation & DF & BY & GY & HI & PH \\
Entry & 54 & $36.9^{\star \star \star}$ & $46.2^{\star \star \star}$ & $36.3^{\star \star \star}$ & $52.6^{\star \star \star}$ \\
Environment & 2 & $4.8^{\star \star \star}$ & $36.5^{\star \star \star}$ & 3.3 & $5.6^{\star \star \star}$ \\
Entry $\times$ Environment & 108 & 9.4 & $12.5^{\star}$ & $12.2^{\star \star}$ & 12.0
\end{tabular}

B. Traits recorded in two environments

\begin{tabular}{lccccc}
\hline Source of variation & DF & SL & SGW & TKW & PM \\
Entry & 54 & $12.5^{\star \star \star}$ & $35.4^{\star \star \star}$ & $15.9^{\star \star \star}$ & $32.5^{\star \star \star}$ \\
Environment & 1 & 2.1 & $35.4^{\star \star}$ & 31.9 & 3.6 \\
Entry $\times$ Environment & 54 & 17.9 & $35.4^{\star}$ & 31.5 & 33.6
\end{tabular}

*Significant at $\alpha=0.05 ;{ }^{* * S i g n i f i c a n t}$ at $\alpha=0.01 ;{ }^{* * * S i g n i f i c a n t}$ at $\alpha=0.001$.

an acid extraction was carried out according to the method recommended by the European Brewery Convention (Manzanares and Sendra, 1996). Briefly, $100 \mathrm{mg}$ of barley flour was weighed. A volume of $10 \mathrm{~mL}$ distilled water was added jointly with $100 \mu \mathrm{L}$ of alpha-amylase and dispersed with a vortex mixer. Then, the tube was boiled for $1 \mathrm{~h}$ and after cooling, $10 \mathrm{ml}$ of sulphuric acid was added. The mixture was homogenised, boiled for $10 \mathrm{~min}$, cooled to room temperature, and finally centrifuged and the aliquot filtered prior to being loaded into the sampler of the flow analyser.

\section{Data Analysis}

Raw data values for agronomic, physiological, and grain quality traits were analysed by employing the analysis of variance using linear mixed models. For this purpose, locations and years were combined into a single factor (environment). Genotypes (entries), environments, and entry $\times$ environment interaction were considered as fixed effects, while the block effect and the plot effect nested in each block as random. Based on this model, the best linear unbiased estimations (BLUEs) were computed for all recorded traits. To identify the best performing lines across and within each environment, entries were analysed in relation to their source material by performing a GGE biplot analysis based on the grain yield BLUEs values of the entries in each distinct environment. In addition, Pearson correlation coefficients between all recorded traits were computed and a heat map was generated based on correlations. Statistical analysis was performed with JMP statistical package ver. 14.0.0.

\section{RESULTS}

\section{Agronomic Performance Traits}

The combined ANOVA revealed a significant effect of the environment for BY, GY, PH, and SGW traits, while there was no effect for HI, SL, TKW, and PM (Table 3). The three environments differed considerably in terms of annual precipitation with Mornag_16 being the driest one with $295 \mathrm{~mm}$ of rainfall, followed by El Kef_16 receiving $325 \mathrm{~mm}$ of rain. A very different annual precipitation pattern was observed the following year when the Mornag_17 environment recorded a total of $458 \mathrm{~mm}$ of rain (Table 2). Hence, in terms of BY the lowest values were recorded at the driest environment Mornag_16 with a mean value of 3.75 t/ha reduced by 46 and $48 \%$ compared to the respective BY values in El Kef_16 and Mornag_17 (Table 4). The same trend was also revealed for GY with the driest environment Mornag_16 to indicate a mean value of $1.46 \mathrm{t} / \mathrm{ha}$, being significantly lower from the mean GY in El Kef_16 and Mornag_17 with the difference exceeding $1 \mathrm{t} / \mathrm{ha}$ (Table 4). Regarding the $\mathrm{PH}$, distinct values were recorded among the three environments, with Mornag_17 demonstrating the tallest stands with an average value of $81.63 \mathrm{~cm}$, followed by a 13 and 33\% reduction at El Kef_16 and Mornag_16 environments, respectively (Table 4). Furthermore, the driest environment Mornag_16 revealed the lowest values for the SGW, with the mean value of $2.13 \mathrm{~g}$ being by $7 \%$ reduced by the respective value in the El Kef_16 environment (Table 4).

Significant entry effects were revealed for all the recorded agronomic traits (Table 3). Almost for all traits the effect of selection status, i.e., first- and second-year HY and LY lines and source materials, as well as the effect of the source variety/landrace of the derived lines was significant (Figure 1). More specifically, the first- and second-year HY lines recorded the highest BY values at El Kef_16 with a total biomass of 7.65 and $7.46 \mathrm{t} / \mathrm{ha}$, respectively, surpassing the original genotypes

TABLE 4 | Agronomic traits means and confidence intervals of barley entries evaluated in different environments in Tunisia.

\begin{tabular}{|c|c|c|c|c|c|c|c|c|c|}
\hline \multirow[b]{2}{*}{ Trait } & \multicolumn{3}{|c|}{ El Kef_16 } & \multicolumn{3}{|c|}{ Mornag_16 } & \multicolumn{3}{|c|}{ Mornag_17 } \\
\hline & Mean & Lower 95\% & Upper 95\% & Mean & Lower 95\% & Upper 95\% & Mean & Lower 95\% & Upper 95\% \\
\hline BY (t/ha) & 6.90 & 6.522 & 7.276 & 3.75 & 3.495 & 4.007 & 7.18 & 6.672 & 7.697 \\
\hline GY (t/ha) & 2.49 & 2.275 & 2.713 & 1.46 & 1.325 & 1.596 & 2.78 & 2.516 & 3.039 \\
\hline $\mathrm{HI}$ & 0.36 & 0.339 & 0.384 & 0.38 & 0.3567 & 0.400 & 0.37 & 0.358 & 0.392 \\
\hline $\mathrm{PH}(\mathrm{cm})$ & 71.04 & 68.717 & 73.362 & 54.73 & 53.209 & 56.258 & 81.63 & 79.749 & 83.505 \\
\hline $\mathrm{SL}(\mathrm{cm})$ & 7.23 & 7.059 & 7.398 & 7.09 & 6.950 & 7.228 & NA & NA & NA \\
\hline SGW (g) & 2.29 & 2.218 & 2.366 & 2.13 & 2.037 & 2.216 & NA & NA & NA \\
\hline TKW (g) & 34.63 & 32.767 & 36.484 & 33.53 & 31.195 & 35.868 & NA & NA & NA \\
\hline PM & 2.67 & 2.545 & 2.788 & 3.19 & 3.037 & 3.337 & NA & NA & NA \\
\hline
\end{tabular}

NA, Not applicable, measurements not made. 

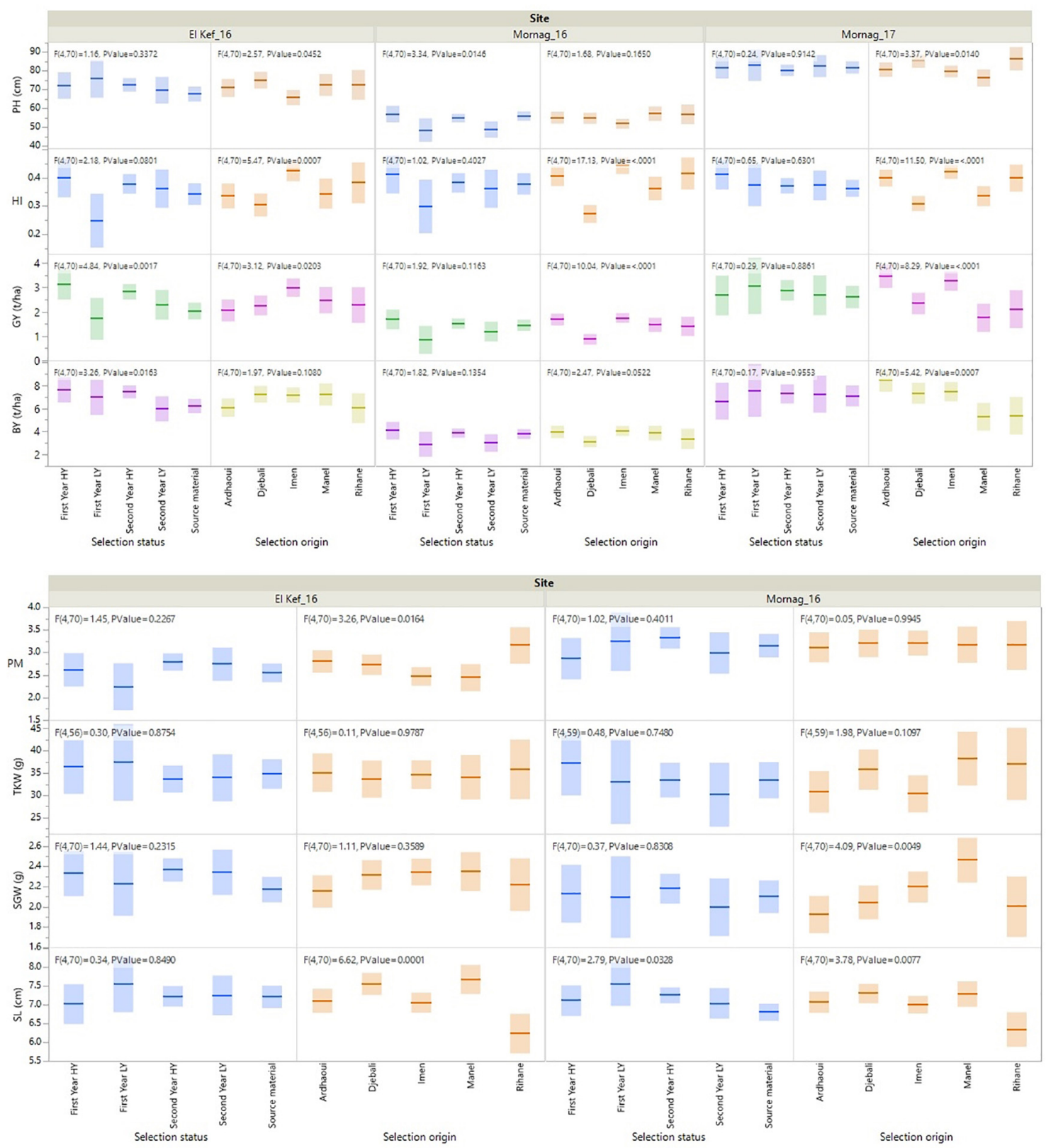

FIGURE 1 | Fit of means for the agronomic traits of barley lines selected under ultra-low density when evaluated under dense stand trials in distinct environments in Tunisia.

by $20 \%$. Moreover, for the same environment, the first- and second-year HY lines showed the highest GY with 3.14 and $2.84 \mathrm{t} / \mathrm{ha}$ outperforming on average the source materials by 36 and $23 \%$, respectively (Figure 1). No significant effects were found for the HI based on the selection status of the lines, even though a clear trend for high $\mathrm{HI}$ values was revealed for the first year $\mathrm{HY}$ lines that recorded a mean $\mathrm{HI}$ value of 0.41 across the three environments compared to the 0.36 $\mathrm{HI}$ value of the source materials. Concerning $\mathrm{PH}$, the firstand second-year LY lines showed the lowest values at the Mornag_16 environment, with significantly shorter stands by a minimum of $6 \mathrm{~cm}$ compared to all other lines (Figure 1).
For the agronomic traits recorded in two environments, the first-year LY lines revealed the longest spikes in the Mornag_16 environment with an average of $7.56 \mathrm{~cm}$, longer by $11 \%$ in comparison to the average length of the source materials. The same trend for the first year LY lines was revealed also at the Kef_16 environment, however, in this case, the differences did not reach the significance level (Figure 1). Despite the differences in terms of SL, no significant effects were found for the SGW based on the selection status of the lines in both environments. The same was also true for the TKW and PM, traits for which the selection status of the lines did not reveal any significant difference (Figure 1). 
When the effect of the source variety/landrace of the derived lines was assessed, the lines derived from variety Imen appeared consistent high values across the three environments with a mean BY of $6.26 \mathrm{t} /$ ha producing on average 12 and $21 \%$ more biomass than the lines acquired from Manel and Rihane varieties, respectively (Figure 1). For the lines originated from the two landraces, the ones from Ardhaoui produced high biomass with a mean BY value of $6.20 \mathrm{t} / \mathrm{ha}$ across the three environments, while the lines from Djebali showed contrasting results being among the high biomass producing lines for the favourable environment of Mornag_17 but ranked amongst the least producing lines for the dry environment of Mornag_16 (Figure 1). In all three environments, lines derived from variety Imen were among the high yielders with a mean GY value of $2.69 \mathrm{t} / \mathrm{ha}$ outperforming significantly the lines acquired from Rihane, Manel, and Djebali by 26,29 , and $32 \%$, respectively (Figure 1). Only lines from Ardhaoui showed similar high GY values to Imen derived lines, even though in one of the environments, El Kef_16, these lines indicated also a significantly lower GY value by $31 \%$ (Figure 1). The same pattern for GY was also depicted for the HI trait, for which lines originated from Imen showed a mean value of 0.43 across the three environments, being significantly higher from the mean HI values of Manel and Djebali derived lines by 19 and 30\%, respectively (Figure 1). Concerning $\mathrm{PH}$, lines originated from Djebali and Rihane were those that demonstrated the tallest stands with the differences being more profound in the Mornag_17 environment, where these lines showed mean $\mathrm{PH}$ values of 86.86 and $85.47 \mathrm{~cm}$, respectively, surpassing the lines derived from Imen and Manel (Figure 1). Three distinct groups based on the source of the derived lines were shaped for SL. Lines originated from Manel and Djebali recorded the longest spikes with 7.49 and $7.44 \mathrm{~cm}$, respectively, significantly higher from the group of Ardhaoui and Imen lines with 7.09 and $7.03 \mathrm{~cm}$, as well as from the lines derived from variety Imen, which showed the shortest spikes with a mean value of $6.29 \mathrm{~cm}$ across the two environments that the measurement recorded (Figure 1). For the SGW, differentiation was found only in Mornag_17, where the lines acquired from Manel recorded a mean SGW value of $2.47 \mathrm{~g}$ being higher by 17,19 , and $22 \%$ from the respective values of the lines originated from Djebali, Rihane, and Ardhaoui (Figure 1). For PM, the lines acquired from Rihane showed higher susceptibility in the environment Kef_16 compared to all other lines recording average symptoms higher than the value of 3 in the disease scale (Figure 1). No differentiation was revealed for the TKW based on the source of the variety/landrace of the derived lines (Figure 1).

Among all agronomic traits, a significant genotype $\times$ environment interaction $(G \times E)$ was observed for GY, HI, and SGW. No significant $\mathrm{G} \times \mathrm{E}$ effects were detected for BY, PH, SL, TKW, and PM with the lines demonstrating a consistent performance across all the environments for these traits (Table 3). To a large extent, the significant $\mathrm{G} \times \mathrm{E}$ effects for GY were due to the contrasting performance of first-year LY lines, which were found to be the less productive lines in El Kef_16 and Mornag_16 environments showing a significant gap in GY compared to the first- and second-year HY lines by 47

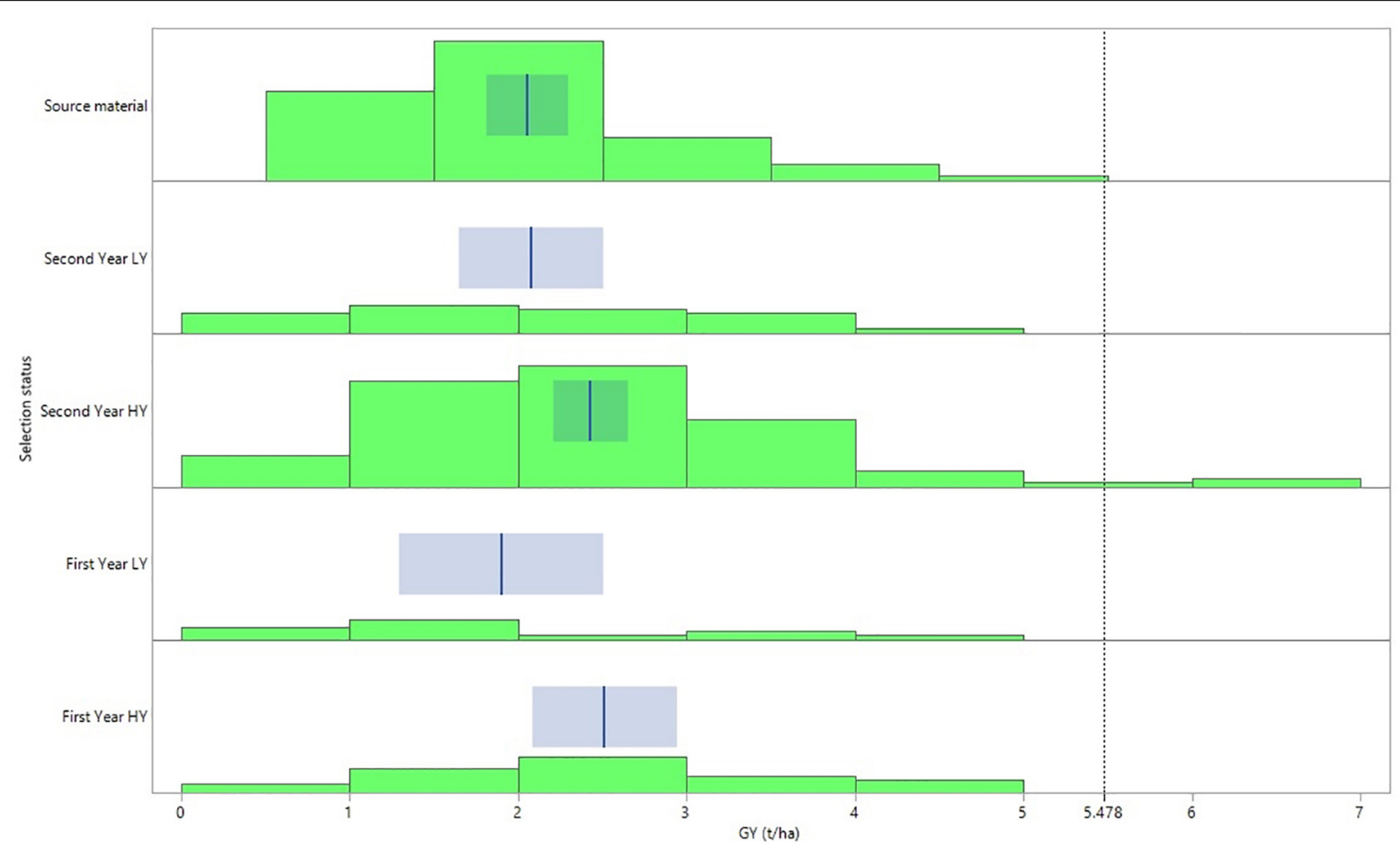

FIGURE 2 | Distribution graph and fit of means for grain yield performance according to the selection status of the barley lines evaluated under dense stand trials in three environments in Tunisia. 
and $41 \%$, respectively, while ranked at the top as an average GY performance in the environment of Mornag_17, even though the differences with the other lines did not reach significance levels (Figure 1). An increase in HI at Mornag_17 environment was also apparent in the first year LY lines, since this index increased for these lines from 0.28 in El Kef_16 and Mornag_16 to 0.38 in Mornag_17, while all other lines maintained the same value of HI across all environments (Figure 1).

Despite the significant $G \times E$ effect for GY, the general pattern across the three environments reflected with high consistency the selection status of the lines (Figure 2). Thus, the first- and second-year HY lines demonstrated the higher mean values for grain yield with 2.51 and $2.43 \mathrm{t} / \mathrm{ha}$, significantly outperforming the source materials. The source materials in turn revealed the same GY mean value with the second year LY lines reaching at 2.05 and $2.07 \mathrm{t} / \mathrm{ha}$, respectively. The least performing lines in terms of grain yield were the first-year LY lines with a mean GY of $1.90 \mathrm{t} /$ ha across the three environments (Figure 2). Furthermore, the group of the second year HY lines was the only one in which some of the lines demonstrated a mean GY across the three environments that exceeded the right cutting-edge threshold value of the curve (5.478 t/ha), defined by the overall mean GY value plus three standard deviations (Figure 2).

To avoid biased assumptions from a joint analysis due to the significant effects of the source material of the derived lines, GGE biplot analysis was performed separately for each of the different source varieties/landraces and their respective derived lines (Figure 3). Based on the analysis, the three environments were very contrasting for the lines derived from Ardhaoui and none of the lines recorded high grain yield in all three environments. Combining environments by two showed that most of the first- and second-year HY lines demonstrated high grain yield, while the first- and second- year LY lines, as well as the original population of Ardhaoui, either performed well only in one environment each time or their performance was poor for all the three environments (Figure 3). Four second-year HY lines from Djebali (DH2-3, DH2-4, DH2-5, and DH12-1) revealed high grain yield across all environments compared to their original population, with their scores to be plotted among the vectors that defined the three evaluation environments (Figure 3). Contrary, the second-year LY lines (DH2-L0 and DH12-L0) were the ones with the lowest grain yield among all

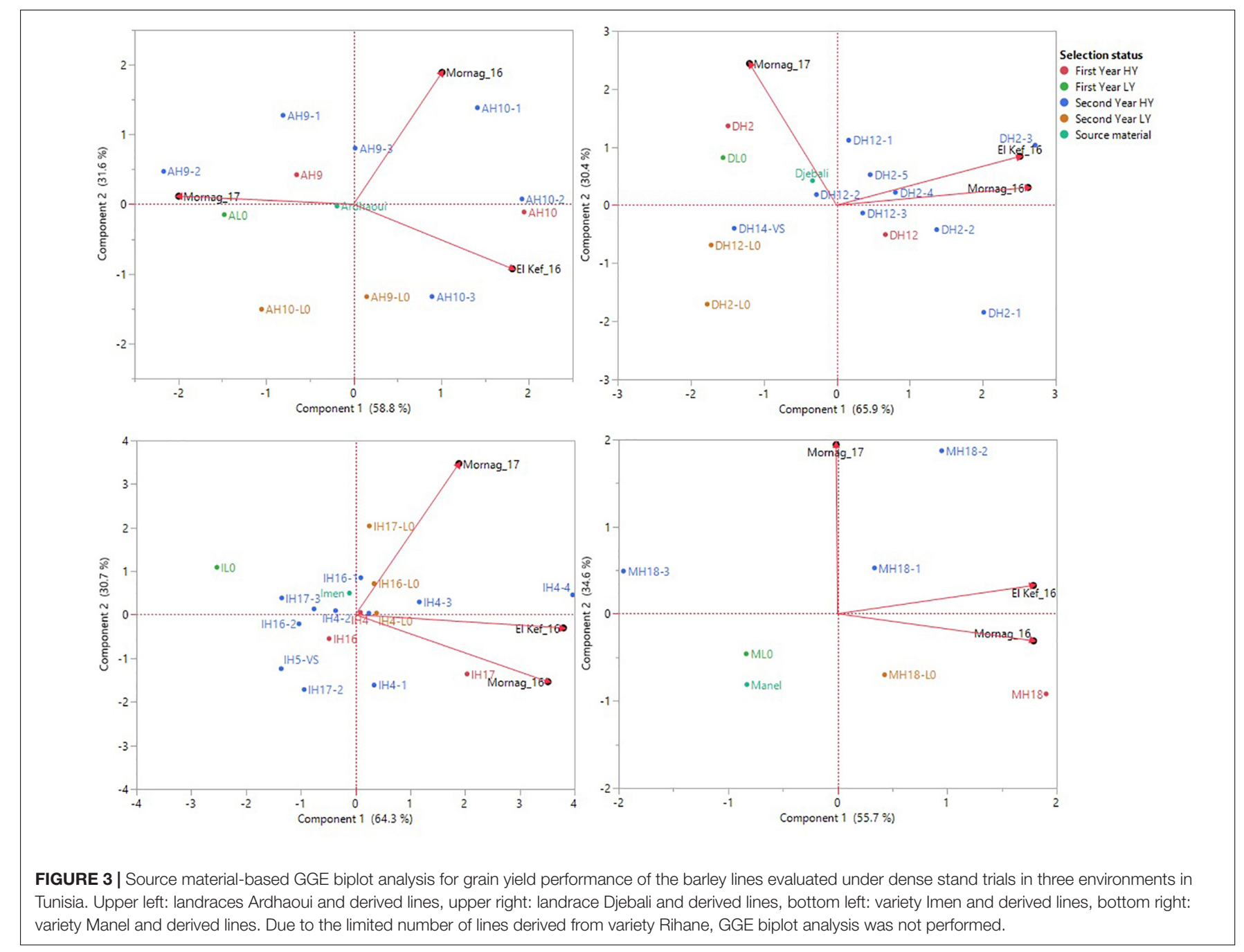


Djebali lines (Figure 3). A more diverse pattern of selection status revealed high grain yield across the three environments for the lines derived from the variety Imen. Two second-year HY lines (IH4-4 and IH4-3) were predominantly the ones showing the highest grain yield for all three environments. Furthermore, line IH4-4 was the one that revealed consistently the highest grain yield for the three environments amongst all the entries tested, ranking first in El Kef_16 and third in Mornag_16 and Mornag_17 with a mean grain yield of 4.44 t/ha (Figure 3). Another one second-year HY line (IH17-1) and one secondyear LY line (IH4-L0) derived from variety Imen showed good performance for grain yield for all three environments, while surprisingly three second-year HY lines (IH16-2, IH17-2, and IH5-VS) and one first-year HY line (IH16) were those with poor performance in all three environments (Figure 3). Having Manel as source material, two second-year HY lines (MH18-2 and MH18-1) showed consistency in terms of high grain yield in all the three environments, contrary to one first-year LY line and the source material of variety Manel that demonstrated low grain yield in each environment that the evaluation took place (Figure 3 ).

\section{Physiological Parameters}

Regarding the physiological parameters, combined ANOVA revealed significant environmental effects for SPAD and LCT. Mornag_16 environment-induced higher values for the barley lines in comparison to El Kef_16 (Tables 5, 6). However, no significant $\mathrm{G} \times \mathrm{E}$ effects were revealed for none of the recorded physiological parameters in the trials (Table 5).

Significant entry effects were revealed for these physiological traits (Table 5). Across all environments, the second year HY line IH4-4, which showed a consistent elite performance in terms of grain yield, was the one that exhibited the highest values for the ratios related to the photosynthetic activity with 0.76 for $F_{v} / F_{m}$ and 3.3 for $\mathrm{F}_{\mathrm{V}} / \mathrm{F}_{0}$, significantly higher than the respective ratios of almost all other lines (Figure 4). Meanwhile, its source variety Imen was ranked among the entries that showed the lowest ratios for the two parameters of PSII (Figure 4). No other specific pattern, however, was observed, by means of selection status or source materials from which the lines were derived, regarding the $\mathrm{F}_{\mathrm{v}} / \mathrm{F}_{\mathrm{m}}$ and $\mathrm{F}_{\mathrm{v}} / \mathrm{F}_{0}$ ratios (Figure 4). For LCT the second year HY line IH4-4 was again the one indicating the highest value among all other lines with a mean leaf canopy temperature of $25.7^{\circ} \mathrm{C}$ across all environments (Figure 4). Even though there was no specific pattern for LCT in terms of selection status or source material from which the lines were derived, a trend for high

TABLE 5 | Genotypic and environmental effects and their interaction on the physiological parameters of barley lines selected under ultra-low density when evaluated under dense stand trials in different environments in Tunisia.

\begin{tabular}{lcccccc}
\hline Source of variation & DF & $\mathbf{F}_{\mathbf{v}} / \mathbf{F}_{\mathbf{m}}$ & $\mathbf{F}_{\mathbf{v}} / \mathbf{F}_{\mathbf{0}}$ & $\mathbf{D F}$ & SPAD & LCT \\
\hline Entry & 54 & $17.7^{\star \star \star}$ & $34.0^{\star \star \star}$ & 54 & $15.2^{\star \star \star}$ & $26.3^{\star \star \star}$ \\
Environment & 2 & 1.2 & 1.5 & 1 & $2.3^{\star \star \star}$ & $1.5^{\star}$ \\
Entry $\times$ Environment & 108 & 6.5 & 6.0 & 54 & 19.7 & 12.1 \\
\hline
\end{tabular}

*Significant at $\alpha=0.05 ;{ }^{* * *}$ Significant at $\alpha=0.001$.
LCT values was observed for all the original varieties/landraces that were ranked among the top entries indicating high mean temperature values (Figure 4). As for the SPAD parameter, a trend for low SPAD values appeared for the lines derived by Djebali with a mean of 45.66 . However, this trend did not reach a significant level when lines from Djebali were compared to the lines of other source materials (Figure 4).

\section{Grain Quality Parameters}

Significant environmental effects on grain quality were detected for seed colour parameters as well as for the starch content (Table 7). The environment of Mornag_16 favoured the colour lightness and colour intensity of the grains with the three-colour parameters recording mean values of 152.55 for CLR_a, 119.47 for CLR_b, and 174.68 for CLR_L, significantly higher than the ones in El Kef_16, where the mean values for CLR_a, CLR_b, and CLR_L were 148.90, 114.05, and 172.29, respectively (Table 8). The starch grain content appeared to be higher in El Kef_16 with a mean value of $51.67 \%$ surpassing the respective mean starch content value of $50.43 \%$ in the Mornag_16 environment (Table 8). Regarding the $\mathrm{G} \times \mathrm{E}$ interaction, only a few of the considered grain quality parameters showed a significant effect. Thus, significant $\mathrm{G} \times \mathrm{E}$ interactions were limited to CLR_b and $\beta$-GLC, while all other grain quality parameters did not reveal any interaction between the barley lines and the environment (Table 7).

Highly significant entry effects were indicated for all the grain quality parameters, from the grain shape and size (PRM, LNG, WDT) up to the colouration (CLR_a, CLR_b, CLR_L) and seed nutrient content (PRT, STRCH, $\beta$-GLC) (Table 7). A clear trend based on the source materials that the lines derived was observed for the grain shape and size traits. Lines originating from Djebali showed significantly longer grains than all other lines with a mean LNG value of $11.24 \mathrm{~mm}$. On the contrary, lines derived from variety Imen were the ones with the shortest grain length with a mean value of $9.93 \mathrm{~mm}$ (Figure 5). Djebali lines also showed a high value for grain width ranked second after the lines acquired from Manel for the specific trait. Thus, the mean WDT values for lines acquired from Manel was $3.02 \mathrm{~mm}$, significantly higher than the value of 2.97, which was the mean value of lines derived from Djebali (Figure 5). The high LNG and WDT values from Djebali lines had a direct impact on the grain perimeter for which these lines were top-ranked with a mean value of $33.14 \mathrm{~mm}$ with a difference of a minimum of $3 \mathrm{~mm}$ in terms of perimeter compared to all other lines (Figure 5).

Regarding the lightness of the grain colour, no specific trend was indicated for barley lines. Some of the lines originated from Manel and Djebali, such as DH12-3, DH2-3, DH12-L0, MH18, MH18-2 appeared to be the ones with the lighter grain colour indicating significantly higher values for CLR_L compared to most of the other lines (Figure 5). However, these differences were more profound and source material specific for colour intensity. In this case, lines originated from Djebali showed, on average, higher values for CLR_a and CLR_b with a mean of 152.13 and 119.75 , respectively, while lines derived from Imen were the ones that had lower values among all entries with CLR_a mean value 148.99 and CLR_b mean value 113.54 (Figure 5). 
TABLE 6 | Physiological parameters means and confidence intervals of barley entries evaluated in different environments in Tunisia.

\begin{tabular}{|c|c|c|c|c|c|c|c|c|c|}
\hline \multirow[b]{2}{*}{ Trait } & \multicolumn{3}{|c|}{ EI Kef_16 } & \multicolumn{3}{|c|}{ Mornag_16 } & \multicolumn{3}{|c|}{ Mornag_17 } \\
\hline & Mean & Lower 95\% & Upper 95\% & Mean & Lower 95\% & Upper 95\% & Mean & Lower 95\% & Upper 95\% \\
\hline $\mathrm{F}_{\mathrm{v}} / \mathrm{F}_{\mathrm{m}}$ & 0.66 & 0.651 & 0.663 & 0.69 & 0.684 & 0.702 & 0.70 & 0.689 & 0.711 \\
\hline $\mathrm{F}_{\mathrm{v}} / \mathrm{F}_{0}$ & 1.97 & 1.921 & 2.028 & 2.36 & 2.268 & 2.455 & 2.41 & 2.302 & 2.515 \\
\hline SPAD & 42.48 & 41.760 & 43.195 & 51.66 & 51.061 & 52.256 & NA & NA & NA \\
\hline LCT & 20.11 & 19.380 & 20.839 & 23.77 & 23.473 & 24.073 & NA & NA & NA \\
\hline
\end{tabular}

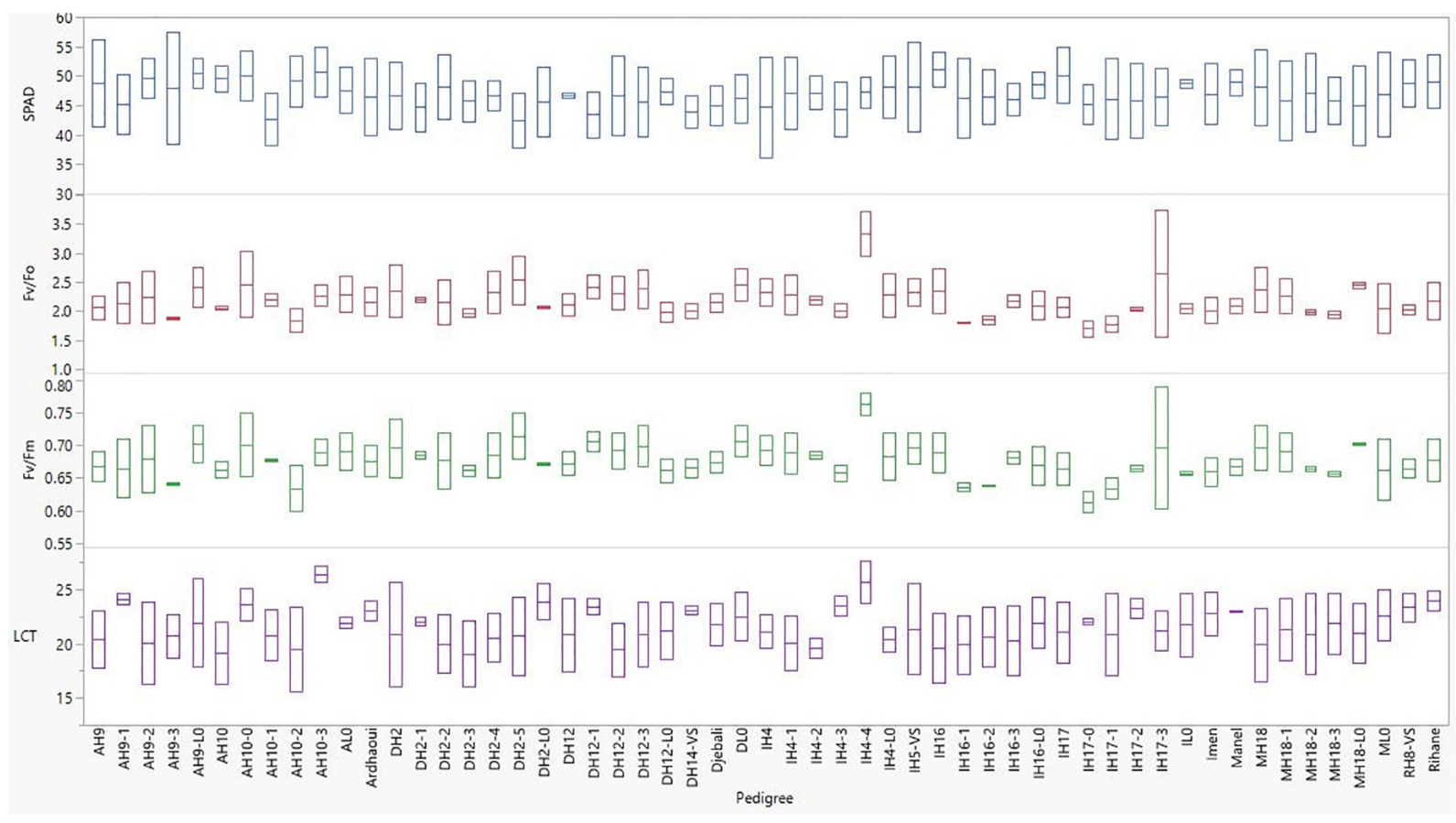

FIGURE 4 | Entry box plots for the physiological parameters measured during the evaluation of the barley lines in the distinct environments in Tunisia.

TABLE 7 | Genotypic and environmental effects and their interaction on the grain quality parameters of barley lines selected under ultra-low density when evaluated under dense stand trials in different environments in Tunisia.

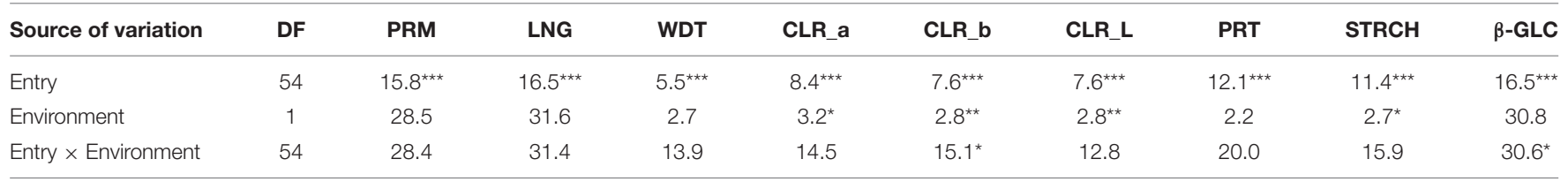

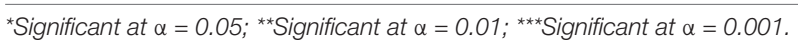

An increase in grain protein content by $2.34 \%$ on average was also revealed for the second-year HY lines in comparison to their respective source materials (Figure 5). This increase was consistent among all different source varieties/landraces and was more profound in the case of Ardhaoui, for which the second year HY lines significantly surpassed the source material of Ardhaoui by $7.34 \%$ for grain protein content (Figure 5). At the same time, $\beta$-glucan content appeared to be reduced among second-year HY lines by $7.24 \%$ in comparison to their respective source materials (Figure 5). The trend was specific to the source material, since the second year HY lines derived from Ardhaoui showed significantly lower $\beta$-glucan content by $9.95 \%$ from their source material, while on the other side the second year HY lines from Manel found by $17.2 \%$ on average higher than original variety Manel in terms of $\beta$-glucan content (Figure 5). Regarding grain starch content, selected HY lines did not reveal, as a general trend, any difference from the source material. However, among all lines, some second-year HY lines derived from Imen (IH4-3, IH16-3, IH4-1, IH17-2, IH16-1, IH4-4) were identified to show significantly higher starch content values among tested entries (Figure 5). On the opposite side, the lines derived from Djebali independently their selection status, along with their original population were those with the lower values for grain starch content (Figure 5). 
TABLE 8 | Grain quality parameters means and confidence intervals of barley entries evaluated in different environments in Tunisia.

\begin{tabular}{|c|c|c|c|c|c|c|}
\hline \multirow[b]{2}{*}{ Trait } & \multicolumn{3}{|c|}{ El Kef_16 } & \multicolumn{3}{|c|}{ Mornag_16 } \\
\hline & Mean & $\begin{array}{l}\text { Lower } \\
95 \%\end{array}$ & $\begin{array}{c}\text { Upper } \\
95 \%\end{array}$ & Mean & $\begin{array}{l}\text { Lower } \\
95 \%\end{array}$ & $\begin{array}{l}\text { Upper } \\
95 \%\end{array}$ \\
\hline PRM (mm) & 31.05 & 30.545 & 31.555 & 30.59 & 30.133 & 31.041 \\
\hline LNG (mm) & 10.50 & 10.314 & 10.684 & 10.31 & 10.145 & 10.473 \\
\hline WDT (mm) & 2.92 & 2.902 & 2.949 & 2.95 & 2.929 & 2.977 \\
\hline CLR_a & 148.90 & 148.231 & 149.559 & 152.45 & 151.577 & 153.318 \\
\hline CLR_b & 114.05 & 113.065 & 115.035 & 119.57 & 118.516 & 120.620 \\
\hline CLR_L & 172.29 & 171.707 & 172.880 & 174.68 & 173.952 & 175.404 \\
\hline PRT (\%) & 10.47 & 10.279 & 10.665 & 10.59 & 10.378 & 10.806 \\
\hline STRCH (\%) & 51.67 & 51.371 & 51.964 & 50.43 & 50.200 & 50.669 \\
\hline$\beta$-GLC (\%) & 4.46 & 4.147 & 4.768 & 4.63 & 4.328 & 4.922 \\
\hline
\end{tabular}

\section{Correlations Among Traits}

Based on barley lines' general performance, some distinct clusters of intercorrelated traits were revealed (Figure 6). In particular, GY was positively correlated with the agronomic performance traits of BY $(r=0.88), \mathrm{HI}(r=0.57)$, and $\mathrm{PH}(r=0.47)$ (Figure 6). Surprisingly, no significant correlation was revealed between GY and TKW, as well as between GY and SL (Figure 6). Regarding the correlation to the physiological traits, GY was negatively correlated to SPAD $(r=-0.42)$ and LCT $(r=-0.46)$, even though for LCT the line that revealed consistently the higher grain yield across all environments was the one revealing the higher leaf canopy temperature (Figures 4, 6). On the other hand, the PSII related physiological traits, i.e., $\mathrm{F}_{\mathrm{v}} / \mathrm{F}_{\mathrm{m}}$ and $\mathrm{F}_{\mathrm{v}} / \mathrm{F}_{0}$ did not show any correlation with GY (Figure 6). As far as the grain quality parameters, a significant correlation was found between GY and STRCH $(r=0.68)$, while significant negative correlations were found between GY and CLR_b colour intensity $(r=-0.50)$ (Figure 6). Another interesting cluster for intercorrelated traits was the one shaped among the four measured physiological parameters $\left(\mathrm{F}_{\mathrm{v}} / \mathrm{F}_{\mathrm{m}}, \mathrm{F}_{\mathrm{v}} / \mathrm{F}_{0}, \mathrm{SPAD}, \mathrm{LCT}\right)$ for which the paired correlations were in all cases significant ranging from $r=0.41$ (between SPAD and $\mathrm{F}_{\mathrm{v}} / \mathrm{F}_{\mathrm{m}}$ ) up to $r=0.98$ (between $\mathrm{F}_{\mathrm{v}} / \mathrm{F}_{\mathrm{m}}$ and $\left.\mathrm{F}_{\mathrm{v}} / \mathrm{F}_{0}\right)$ (Figure 6).

\section{DISCUSSION}

In this study, 50 barley lines selected by applying divergent single plant selection at ultra-low density within three commercial cultivars and two Tunisian landraces were evaluated in comparison to their source material in an open field under highly contrasting environmental conditions in Tunisia, ranging from dry (Mornag_16; $295 \mathrm{~mm}$ annual rainfall) to moderately dry (El Kef_16; $325 \mathrm{~mm}$ annual rainfall) up to favourable ones (Mornag_17; $458 \mathrm{~mm}$ annual rainfall). The results of this study revealed that the selection applied under ultra-low density reflected with high consistency the grain yield patterns under dense stands with the first- and second-year HY lines to outperform the source material, and the first year LY lines to rank under all entries in terms of grain yield. These lines were derived after applying intra-cultivar selection within source materials of different genetic backgrounds regarding their genetic constitution. That is, while some genetic diversity was expected to be exploitable within the two landraces, no genetic variation was expected theoretically to occur within the improved barley varieties. However, the present study revealed that even within improved varieties, individual plant selection under ultra-low density was efficient to select for HY lines that outperformed their respective source material across all environments.

Although intra-cultivar variation has long been recognised in crop species (Sprague et al., 1960; Russell et al., 1963; Byth and Weber, 1968), it is oftentimes ignored due to the common belief that elite cultivars are highly homogeneous (Fasoula and Boerma, 2007; Haun et al., 2011). Nevertheless, even within homogeneous gene pools, an intrinsic amount of latent genetic variation may still occur, whereas mechanisms that generate de novo variation may also be present. Residual heterozygosity, due to segregation of parental loci during the breeding process is presumably one source of genetic variation (Haun et al., 2011; Tokatlidis, 2015). On the other hand, additional heterogeneity might stem from de novo generated variation, resulting from spontaneous mutations (Shaw et al., 2000; Ossowski et al., 2010) or via genetic and epigenetic mechanisms, such as intragenic recombination, unequal crossing over, gene duplications, or deletions, DNA methylation, excision or insertion of transposable elements, chromatin alterations, and others (Rasmusson and Phillips, 1997; Sani et al., 2013; Cavrak et al., 2014; Kim and Zilberman, 2014).

Despite the wide variability in terms of annual precipitations among the three testing environments, no significant $\mathrm{G} \times \mathrm{E}$ interactions were found for most of the recorded traits. Thus, the barley lines selected under ultra-low density revealed a high buffering capacity for biological yield, demonstrating similar patterns for biomass production across all environments, regardless of the unpredictable precipitation rates. The plasticity of the selected lines as a response to environmental conditions was also maintained for other agronomic traits, such as plant height, spike length, thousand kernel weight, and powdery mildew resistance. However, a significant $G \times E$ effect was indicated for the grain yield mainly as a response to the strong $\mathrm{G} \times \mathrm{E}$ interactions for the harvest index and the grain weight per spike. Yet, as the high correlation to the biological yield entails the $\mathrm{G} \times \mathrm{E}$ effect for grain yield was marginally significant, implying a good buffering capacity of the selected lines for this particular trait, too. Furthermore, some selected lines were found to outperform their source material and the best checks across all environments consistently.

Buffering capacity is a crucial feature for the development of modern varieties, to tackle the unpredictable environmental conditions by making optimum use of available resources in both marginal and favourable environments. Defining the optimum planting density under these variable and fragile conditions to accomplish the attainable yield depends on many crop parameters, as well as on several factors related to the genotype itself and the applied cultivation practices. In maize, abiotic adversities show a more pronounced effect under dense stands (Berzsenyi and Tokatlidis, 2012; 

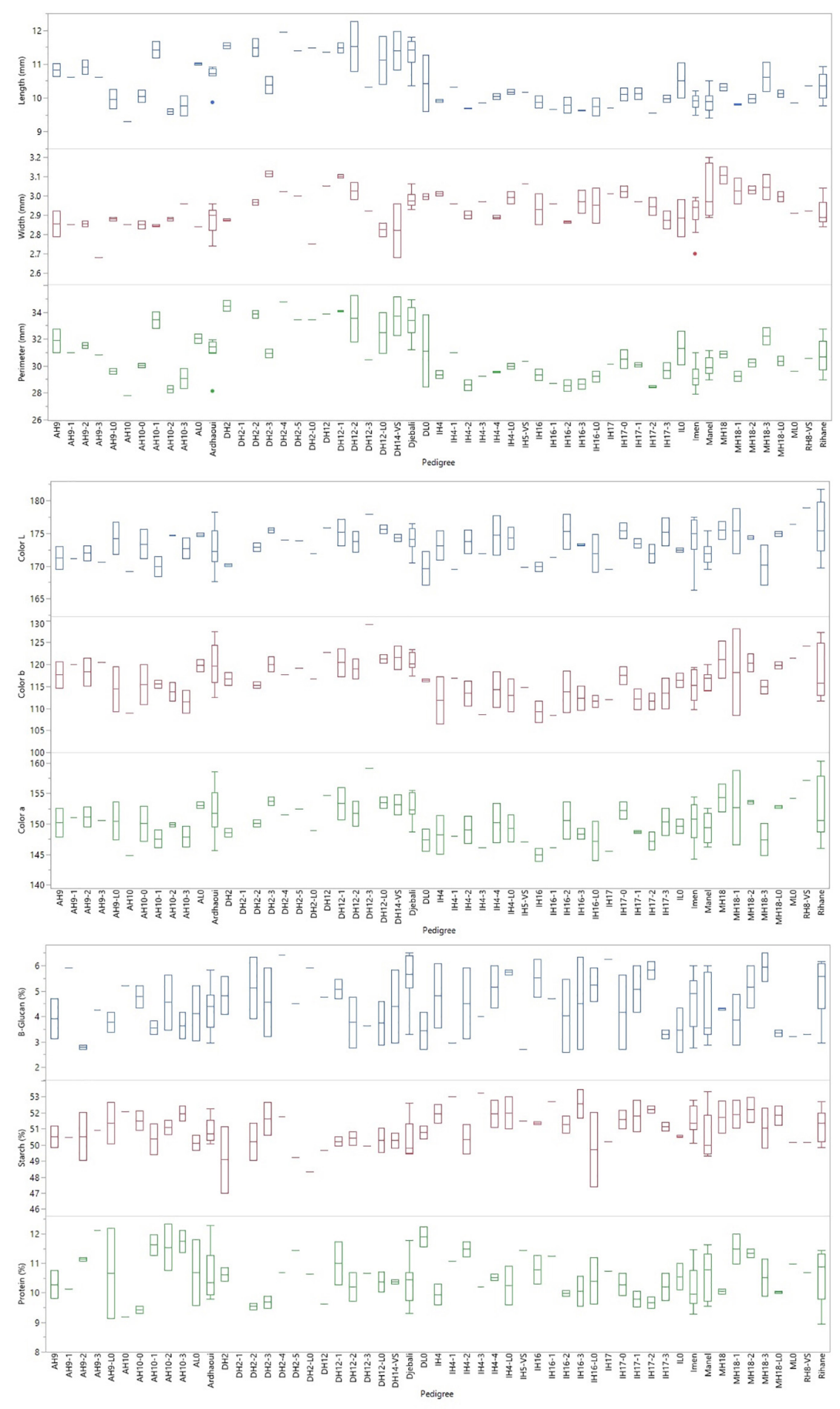

FIGURE 5 | Entry box plots for the grain quality parameters measured during the evaluation of the barley lines in the distinct environments in Tunisia.

Solomon et al., 2017; Mylonas et al., 2020). On the other hand, Bastos et al. (2020), mentioned for wheat that under high-yielding and less limited resources environments the number of plants required to maximise yields was very low, below any commercial recommended number of plants for this crop. However, a higher planting density was needed for the low-yielding environments to sustain maximum yields (Bastos et al., 2020).

To this end, Tokatlidis et al. (2001) indicated the need to extend the lower and upper limits of optimum crop plant density. The authors highlight the concept of developing 


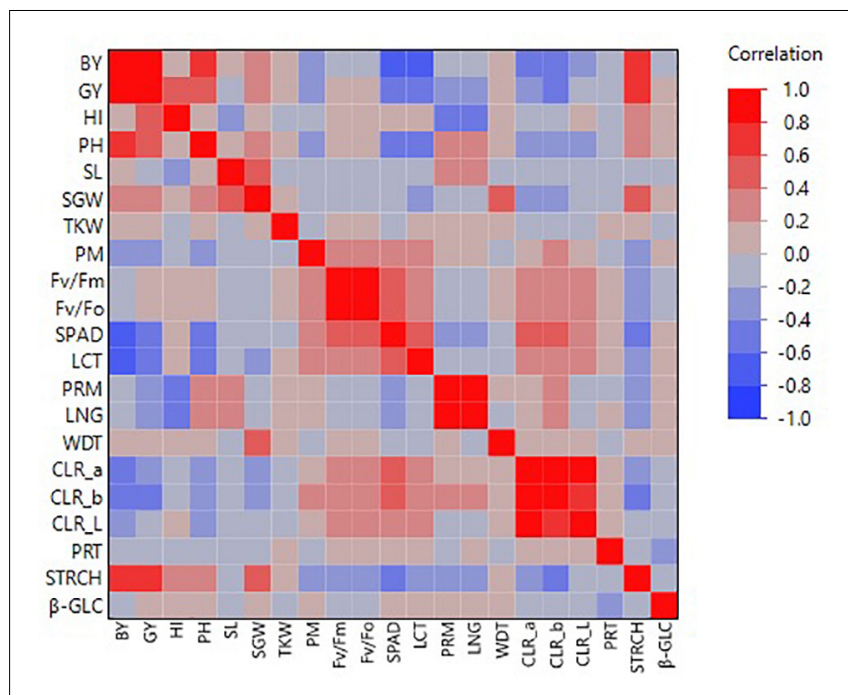

FIGURE 6 | Colour map on pairwise correlations for the different traits recorded during the evaluation of the barley lines in the distinct environments in Tunisia.

density-independent varieties that offer flexibility and plasticity to environmental diversity and secure over-season stability (Tokatlidis et al., 2001; Tokatlidis, 2017). Lower and upper limits of the optimum density are determined by individual plant yield efficiency and tolerance to high densities, respectively (Tokatlidis et al., 2001). Extending the lower limits of the optimum crop density has been proven more challenging than expected. Hence, evidence from research on maize suggests that plant yield potential of maize hybrids remained practically without significant change along the years of maize hybrid development, and it is the hybrid performance as a response to a steadily increasing density rate that is improved (Tollenaar and Lee, 2002; Tokatlidis and Koutroubas, 2004; Duvick, 2005; Gonzalez et al., 2018) or in the best-case scenario, a positive impact on yield components as other sources for yield gain was also identified (Assefa et al., 2018). Given the inverse relationship between the yield of a genotype and its competitive ability (Sedgley, 1991; Fasoula and Fasoula, 1997; Pan et al., 2003; Chatzoglou and Tokatlidis, 2012; Ninou et al., 2014), Tokatlidis (2017) introduced the idea of exploiting in plant breeding the "weak competitor" ideotype. In other words, since under dense stand conditions, the superiority of a plant that stands out could stem from being a strong competitor, while a weak neighbour devoid of genetic competitive ability might be the one with the higher yield potential, Tokatlidis (2017) recommended evaluation and selection of individual plants adequately spaced under a regime that simulates conditions of nil-competition. Evaluation of genotypes under ultra-low density in a regime that practically resembles nil-competition has been successfully also applied as a predictive tool for plant yield efficiency and stability (Sinapidou et al., 2020). Our findings confirm the above remarks, since selection under ultra-low density for high plant yield efficiency, resulted in the selection of superior barley lines with enhanced buffering capacity, revealing high stability in unpredictable environments that ranged from dry (Mornag_2016) up to favourable (Mornag_2017) ones.

Correlation between physiological parameters and agronomic performance traits for the evaluated barley lines showed variable results. According to Fang and Xiong (2015), to overcome drought stress at the physiological level, plants adjust their rates of photosynthesis by modifying photosystem II, inducing the stomatal closure, and lowering the carbohydrate and nitrogen metabolism, as well as the nucleic acid, and protein activity. The effect of drought stress on PSII in plants has been found controversial. Hence, while in some studies chlorophyll fluorescence was found to be useful to evaluate yield performance under rainfed Mediterranean conditions in durum wheat (Araus et al., 1998) and barley (Li et al., 2006), in some others it has been considered as of limited use (Aberkane et al., 2021). On the other hand, leaf canopy temperature has been reported as a useful criterion to select for water-stressed environments and a high correlation has been found between lower canopy temperature and grain yield in wheat (Amani et al., 1996; Reynolds et al., 1998). A significant negative correlation between grain yield and leaf canopy temperature was also revealed from our study, implying that higher grain yield was associated with lower canopy temperature. However, it is worth mentioning that the line which outperformed consistently all other lines across all environments was the one that showed the higher leaf canopy temperature among all the evaluated entries, meaning that other factors are also crucial to determine efficient response to drought conditions. Regarding chlorophyll content, a significant negative correlation was observed between grain yield and SPAD values, which was not expected based on some research evidence that drought and heat stress affect the photosynthetic activity by reducing chlorophyll content (Feng et al., 2014; Sangwan et al., 2018). However, other researchers have reported limited or no association between chlorophyll content and grain yield under heat and drought stress conditions (Pinto et al., 2010; Aberkane et al., 2021).

Good plasticity of barley lines was also indicated for the grain quality parameters since no $G \times E$ effects were revealed for most of the recorded quality traits. Furthermore, the improved agronomic performance of the barley selected lines, induced an indirect positive effect on grain protein content with most of the selected high yielding lines to maintain or even improve their protein content in comparison to their source material. Such results are very promising, particularly under the view of a global trend that has been reported toward the lowering of grain quality in high yielding agronomic conditions and among modern cultivars, because breeders are selecting for grain yield but not for quality (Fan et al., 2008; Laidig et al., 2017; Marcos-Barbero et al., 2021). Nevertheless, as Simmonds (1996) highlighted, despite the consensus for strongly negative correlations between grain yield and protein content in cereals a positive expected relationship also holds by making, however, some compromises between attainable high yield or high protein content. The results of our study indicated that small progress in grain protein content has been achieved, while selecting for high grain yield, in accordance with Simmonds's (1996) remark. Working with lentil crops, following a 2-year selection cycle for 
individual plant yield under ultra-low density, Ninou et al. (2019) ensured that the selection of high yielding lines maintained or even improved their seed quality characteristics.

Overall, the development of varieties with enhanced buffering capacity, characterised by density independence and resource use efficiency is of utmost importance for the farmers to sustain the yield under the unpredictability and inter-annual variation of agricultural environments. Toward this direction, selection for plant yield efficiency at ultra-low-density conditions sounds like a prudent tool to narrow the gap between the actual and the attainable yield and to meet future challenges in agriculture.

\section{CONCLUSION}

Considering the challenges imposed by climate variation and volatility of agricultural environments, the development of modern cultivars with high and stable performance across a wide range of environments is an imperative need. The results of our study revealed that selection for high plant yield efficiency under ultra-low density resulted in the development of high yielding lines with an innate buffering capacity, outperforming their source materials and the best checks consistently under contrasting environments. In addition, the potential at the

\section{REFERENCES}

Aberkane, H., Belkadi, B., Kehel, Z., Filali-Maltouf, A., Tahir, I. S. A., Meheesi, S., et al. (2021). Assessment of drought and heat tolerance of durum wheat lines derived from interspecific crosses using physiological parameters and stress indices. Agronomy 11:695. doi: 10.3390/agronomy11040695

Alessandri, A., De Felice, M., Zeng, N., Mariotti, A., Pan, Y., Cherchi, A., et al. (2014). Robust assessment of the expansion and retreat of Mediterranean climate in the 21st century. Sci. Rep. 4:7211. doi: 10.1038/srep07211

Amani, I., Fisher, R. A., and Reynolds, M. P. (1996). Canopy temperature depression association with yield of irrigated spring wheat cultivars in hot climates. J. Agron. Crop Sci. 176, 119-129. doi: 10.1111/j.1439-037X.1996. tb00454.x

Araus, J. L., Amaro, T., Voltas, J., Nakkoul, H., and Nachit, M. M. (1998). Chlorophyll fluorescence as a selection criterion for grain yield in durum wheat under Mediterranean conditions. Field Crops Res. 55, 209-223. doi: 10.1016/ S0378-4290(97)00079-8

Assefa, Y., Carter, P., Hinds, M., Bhalla, G., Schon, R., Jeschke, M., et al. (2018). Analysis of long term study indicates both agronomic optimal plant density and increase maize yield per plant contributed to yield gain. Sci. Rep. 8:4937. doi: 10.1038/s41598-018-23362-x

Assefa, Y., Vara Prasad, P. V., Carter, P., Hinds, M., Bhalla, G., Schon, R., et al. (2016). Yield responses to planting density for us modern corn hybrids: a synthesis-analysis. Crop Sci. 56:2802. doi: 10.2135/cropsci2016.04.0215

Bastos, L. M., Carciochi, W., Lollato, R. P., Jaenisch, B. R., Rezende, C. R., Schwalbert, R., et al. (2020). Winter wheat yield response to plant density as a function of yield environment and tillering potential: a review and field studies. Front. Plant Sci. 11:54. doi: 10.3389/fpls.2020.00054

Bekele, S., Yoseph, T., and Ayalew, T. (2020). Growth, protein content, yield and yield components of malt barley (Hordeum vulgare L.) varieties in response to seeding rate at Sinana district. Southeast Ethiopia. Int. J. Appl. Agric. 6, 61-71. doi: 10.11648/j.ijaas.20200604.12

Ben Ghanem, H., Najar, A., Udupa, S., Kumari, S. G., Amri, A., Rezgui, S., et al. (2018). Exploiting intra-cultivar variation to select for Barley yellow dwarf virus-PAV (BYDV-PAV) resistance in barley. Can. J. Plant Sci. 98, 930-946. doi: $10.1139 /$ cjps-2017-0364 nil-competition regime for efficient selection within narrow gene pools has been well demonstrated. Furthermore, results suggest that single-plant selection under ultra-low density could serve as an effective strategy for developing high-yielding barley varieties maintaining concurrently a high grain quality profile.

\section{DATA AVAILABILITY STATEMENT}

The raw data supporting the conclusions of this article will be made available by the authors, without undue reservation.

\section{AUTHOR CONTRIBUTIONS}

AT drafted the manuscript. AT and HBG conceptualised the study and designed the field trials. HBG coordinated the field trials and the collection of agronomic and physiological traits. AE-B performed the grain quality analysis and collected and curated the quality data. ZK and AT coordinated data curation and performed the statistical analysis. All authors contributed to the development of the entire manuscript and reviewed and edited the final version.

Bento, V. A., Ribeiro, A. F. S., Russo, A., Gouveia, C. M., Cardoso, R. M., and Soares, P. M. M. (2021). The impact of climate change in wheat and barley yields in the Iberian Peninsula. Sci. Rep. 11:15484. doi: 10.1038/s41598-021-95014-6

Berzsenyi, Z., and Tokatlidis, I. S. (2012). Density dependence rather than maturity determines hybrid selection in dryland maize production. Agron. J. 104, 331336. doi: 10.2134/agronj2011.0205

Brisson, N., Gate, Ph, Gouache, D., Charmet, G., Oury, F.-X., and Huard, F. (2010). Why are wheat yields stagnating in Europe? A comprehensive data analysis for France. Field Crops Res. 119, 201-212. doi: 10.1016/j.fcr.2010.07.012

Byth, D. E., and Weber, C. R. (1968). Effects of genetic heterogeneity within two soybean populations. I. Variability within environments and stability across environments. Crop Sci. 8, 44-47. doi: 10.2135/cropsci1968. 0011183X000800010014x

Cammarano, D., Ceccarelli, S., Grando, S., Romagosa, I., Benbelkacem, A., Akar, T., et al. (2019). The impact of climate change on barley yield in the Mediterranean basin. Eur. J. Agron. 106, 1-11. doi: 10.1016/j.eja.2019.03.002

Carciochi, W. D., Schwalbert, R., Andrade, F. H., Corassa, G. M., Carter, P., Gaspar, A. P., et al. (2019). Soybean seed yield response to plant density by yield environment in North America. Agron. J. 111:1923. doi: 10.2134/agronj2018. 10.0635

Cavrak, V. V., Lettner, N., Jamge, S., Kosarewicz, A., Bayer, L. M., and Mittelsten Scheid, O. (2014). How a retrotransposon exploits the plant's heat stress response for its activation. PLoS Genet. 10:e1004115. doi: 10.1371/journal.pgen. 1004115

Chapagain, T., and Good, A. (2015). Yield and Production Gaps in Rainfed Wheat, Barley, and Canola in Alberta. Front. Plant Sci. 6:990. doi: 10.3389/fpls.2015. 00990

Chatzoglou, T. H., and Tokatlidis, I. S. (2012). Decision on germplasm choice to apply breeding within a local population of common vetch is affected by crowding. Span. J. Agric. Res. 10, 752-755. doi: 10.5424/sjar/2012103-641-11

Dawson, I. K., Russell, J., Powell, W., Steffenson, B., Thomas, W. T. B., and Waugh, R. (2015). Barley: a translational model for adaptation to climate change. New Phytol. 206, 913-931. doi: 10.1111/nph.13266

Diffenbaugh, N. S., and Giorgi, F. (2012). Climate change hotspots in the CMIP5 global climate model ensemble. Clim. Change 114, 813-822. doi: 10.1007/ s10584-012-0570-x 
Duvick, D. N. (2005). The contribution of breeding to yield advances in maize (Zea mays L.). Adv. Agron. 86, 83-145. doi: 10.1016/S0065-2113(05)86002-X

Fan, M. S., Zhao, F. J., Fairweather-Tait, S. J., Poulton, P. R., Dunham, S. J., and McGrath, S. P. (2008). Evidence of decreasing mineral density in wheat grain over the last 160 years. J. Trace Elem. Med. Biol. 22, 315-324. doi: 10.1016/j. jtemb.2008.07.002

Fang, Y., and Xiong, L. (2015). General mechanisms of drought response and their application in drought resistance improvement in plants. Cell. Mol. Life Sci. 72, 673-689. doi: 10.1007/s00018-014-1767-0

FAOSTAT (2021). Food and Agriculture Organization of the United Nations Statistics Division Portal. Available online at: URL https://www.fao.org/faostat/ en/\#data/QCL (accessed on Oct 30, 2021)

Farrior, C. E., Tilman, D., Dybzinski, R., Reich, P. B., Levin, S. A., and Pacala, S. W. (2013). Resource limitation in a competitive context determines complex plant responses to experimental resource additions. Ecology 94, 2505-2517. doi: 10.1890/12-1548.1

Fasoula, D. A., and Fasoula, V. A. (1997). Competitive ability and plant breeding. Plant Breed. Rev. 14, 89-138. doi: 10.1002/9780470650073.ch4

Fasoula, V. A., and Boerma, H. R. (2007). Intra-cultivar variation for seed weight and other agronomic traits within three elite soybean cultivars. Crop Sci. 47, 367-373. doi: 10.2135/cropsci2005.09.0334

Fasoula, V. A., and Fasoula, D. A. (2000). Honeycomb breeding: principles and applications. Plant Breed. Rev. 18, 177-250. doi: 10.1002/978047065015 8.ch4

Fasoula, V. A., and Fasoula, D. A. (2002). Principles underlying genetic improvement for high and stable crop yield potential. Field Crop Res. 75, 191-209. doi: 10.1016/S0378-4290(02)00026-6

Fasoulas, A. C. (1988). The Honeycomb Methodology of Plant Breeding. Thessaloniki: Fasoulas.

Fasoulas, A. C. (1993). Principles of Crop Breeding. Thessaloniki: Fasoulas.

Fasoulas, A. C., and Fasoula, V. A. (1995). Honeycomb selection designs. Plant Breed. Rev. 13, 87-139. doi: 10.1002/9780470650059.ch3

Feng, B., Liu, P., Li, G., Dong, S. T., Wang, F. H., Kong, L. A., et al. (2014). Effect of heat stress on the photosynthetic characteristics in flag leaves at the grain-filling stage of different heat-resistant winter wheat varieties. J. Agro. Crop Sci. 200, 143-155. doi: 10.1111/jac. 12045

Gonzalez, V. H., Tollenaar, M., Bowman, A., Good, B., and Lee, E. A. (2018). Maize yield potential and density tolerance. Crop Sci. 58, 472-485. doi: 10.2135/ cropsci2016.06.0547

Haun, W. J., Hyten, D. L., Xu, W. W., Gerhardt, D. J., Albert, T. J., Richmond, T., et al. (2011). The composition and origins of genomic variation among individuals of the soybean reference cultivar Williams 82. Plant Physiol. 155, 645-655. doi: 10.1104/pp.110.166736

Henson, R. (2011). The Rough Guide to Climate Change. The Symptoms, The Science, The Solutions. London: Penguim Books Ltd, 416.

Hochman, Z., and Horan, H. (2018). Causes of wheat yield gaps and opportunities to advance the water-limited yield frontier in Australia. Field Crops Res. 228, 20-30. doi: 10.1016/j.fcr.2018.08.023

Jedel, P. E., and Helm, J. H. (1995). Agronomic response to seeding rate of twoand six-rowed barley cultivars in central Alberta. Can. J. Plant Sci. 75, 315-320. doi: $10.4141 /$ cjps $95-055$

Kim, M. Y., and Zilberman, D. (2014). DNA methylation as a system of plant genomic immunity. Trends Plant Sci. 19, 320-326. doi: 10.1016/j.tplants.2014. 01.014

Kyriakou, D. T., and Fasoulas, A. C. (1985). Effects of competition and selection pressure on yield response in winter rye (Secale cereale L.). Euphytica 34, 883-895. doi: 10.1007/BF00035428

Laidig, F., Piepho, H. P., Rentel, D., Drobek, T., Meyer, U., and Huesken, A. (2017). Breeding progress, variation, and correlation of grain and quality traits in winter rye hybrid and population varieties and national on-farm progress in Germany over 26 years. Theor. Appl. Genet. 130, 981-998. doi: 10.1007/s00122-017-2 $865-9$

Li, R., Guo, P., Michael, B., Stefania, G., and Salvatore, C. (2006). Evaluation of chlorophyll content and fluorescence parameters as indicators of drought tolerance in barley. Agric. Sci. China 5, 751-757. doi: 10.1016/S1671-2927(06) 60120-X

Lin, M., and Huybers, P. (2012). Reckoning wheat yield trends. Environ. Res. Lett. 7:024016. doi: 10.1088/1748-9326/7/2/024016
Manzanares, P., and Sendra, J. M. (1996). Determination of total $(1 \rightarrow 3),(1 \rightarrow 4)$ $\beta$-D-glucan in barley and malt flour samples. J. Cereal Sci. 23, 293-296. doi: 10.1006/jcrs. 1996.0030

Marcos-Barbero, E. L., Pérez, P., Martínez-Carrasco, R., Arellano, J. B., and Morcuende, R. (2021). Genotypic variability on grain yield and grain nutritional quality characteristics of wheat grown under elevated $\mathrm{CO} 2$ and high temperature. Plants 10:1043. doi: 10.3390/plants10061043

Matsuyama, H., and Ookawa, T. (2020). The effects of seeding rate on yield, lodging resistance and culm strength in wheat. Plant Prod. Sci. 23, 322-332. doi: 10.1080/1343943X.2019.1702469

Mueller, N. D., Gerber, J. S., Johnston, M., Ray, D. K., Ramankutty, N., and Foley, J. A. (2012). Closing yield gaps through nutrient and water management. Nature 490, 254-257. doi: 10.1038/nature11420

Mylonas, I., Sinapidou, E., Remountakis, E., Sistanis, I., Pankou, C., Ninou, E., et al. (2020). Improved plant yield efficiency alleviates the erratic optimum density in maize. Agron. J. 112, 1690-1701. doi: 10.1002/agj2.20187

Newton, A. C., Flavell, A. J., George, T. S., Leat, P., Mullholland, B., Ramsay, L., et al. (2011). Crops that feed the world 4. Barley: a resilient crop? Strengths and weaknesses in the context of food security. Food Sec. 3, 141-178. doi: 10.1007/s12571-011-0126-3

Ninou, E., Papathanasiou, F., Vlachostergios, D. N., Mylonas, I., Kargiotidou, A., Pankou, C., et al. (2019). Intense breeding within lentil landraces for highyielding pure lines sustained the seed quality characteristics. Agriculture 9:175. doi: 10.3390/agriculture 9080175

Ninou, E. G., Mylonas, I. G., Tsivelikas, A., Ralli, P., Dordas, C., and Tokatlidis, I. S. (2014). Wheat landraces are better qualified as potential gene pools at ultraspaced rather than densely grown conditions. Sci. World J. 2014:957472. doi: $10.1155 / 2014 / 957472$

O’Donovan, J. T., Turkington, T. K., Edney, M. J., Juskiw, P. E., McKenzie, R. H., Harker, K., et al. (2012). Effect of seeding date and seeding rate on malting barley production in western Canada. Can. J. Plant Sci. 92, 321-330. doi: 10. 4141/cjps2011-130

Ossowski, S., Schneeberger, K., Lucas-Lledó, J. I., Warthmann, N., Clark, R. M., Shaw, R. G., et al. (2010). The rate and molecular spectrum of spontaneous mutations in Arabidopsis thaliana. Science 327, 92-94. doi: 10.1126/science. 1180677

Pagano, E., and Maddonni, G. A. (2007). Intra-specific competition in maize: early established hierarchies differ in plant growth and biomass partitioning to the ear around silking. Field Crops Res. 101, 306-320. doi: 10.1016/j.fcr.2006.12.007

Pan, X., Wang, G., Yang, H., and Wei, X. (2003). Effect of water deficits on withinplot variability in growth and grain yield of spring wheat in northwest China. Field Crops Res. 80, 195-205. doi: 10.1016/S0378-4290(02)00175-2

Peltonen-Sainio, P., Jauhiainen, L., and Laurila, I. P. (2009). Cereal yield trends in northern European conditions: changes in yield potential and its realisation. Field Crops Res. 110, 85-90. doi: 10.1016/j.fcr.2008.07.007

Perrott, L. A., Strydhorst, S. M., Hall, L. M., Yang, R. C., Pauly, D., Gill, K. S., et al. (2018). Advanced agronomic practices to maximize feed barley yield, quality, and standability in Alberta, Canada. I. Responses to plant density, a plant growth regulator, and foliar fungicides. Agron. J. 110, 1447-1457. doi: 10.2134/agronj2017.12.0683

Pinto, R. S., Reynolds, M. P., Mathews, K. L., McIntyre, C. L., Olivares-Villegas, J.-J., and Chapman, S. C. (2010). Heat and drought adaptive QTL in a wheat population designed to minimize confounding agronomic effects. Theor. Appl. Genet. 121, 1001-1021. doi: 10.1007/s00122-010-1351-4

Rasmusson, D. C., and Phillips, R. L. (1997). Plant breeding progress and genetic diversity from de novo variation and elevated epistasis. Crop Sci. 37, 303-310. doi: 10.2135/cropsci1997.0011183X003700020001x

Ray, D., Gerber, J., MacDonald, G., and West, P. (2015). Climate variation explains a third of global crop yield variability. Nat. Commun. 6:5989. doi: 10.1038/ ncomms 6989

Reynolds, M. P., Singh, R. P., Ibrahim, A., Ageeb, O. A. A., Larqué-Saavedra, A., and Quick, J. S. (1998). Evaluating physiological traits to complement empirical selection for wheat in warm environments. Euphytica 100, 85-94. doi: 10.1023/A:1018355906553

Rossini, M. A., Maddonni, G. A., and Otegui, M. E. (2011). Inter-Plant Competition for resources in maize crops grown under contrasting nitrogen supply and density: variability in plant and ear growth. Field Crops Res. 121, 373-380. doi: $10.1016 /$ j.fcr.2011.01.003 
Russell, W. A., Sprague, G. F., and Penny, L. H. (1963). Mutations affecting quantitative characters in long-time inbred lines of maize. Crop Sci. 3, 175-178. doi: 10.2135/cropsci1963.0011183X0003000 20026x

Sangwan, S., Ram, K., Rani, P., and Munjal, R. (2018). Effect of terminal high temperature on chlorophyll content and normalized difference vegetation index in recombinant inbred lines of bread wheat. Int. J. Curr. Microbiol. App. Sci. 7, 1174-1183. doi: 10.20546/ijcmas.2018.706.139

Sani, E., Herzyk, P., Perrella, G., Colot, V., and Amtmann, A. (2013). Hyperosmotic priming of Arabidopsis seedlings establishes a long-term somatic memory accompanied by specific changes of the epigenome. Genome Biol. 14:R59. doi: 10.1186/gb-2013-14-6-r59

Schils, R., Olesen, J. E., Kersebaum, K. C. H., Rijk, B., Oberforster, M., Kalyada, V., et al. (2018). Cereal yield gaps across Europe. Eur. J. Agron. 101, 109-120. doi: 10.1016/j.eja.2018.09.003

Sedgley, R. H. (1991). An appraisal of the Donald ideotype after 21 years. Field Crops Res. 26, 93-112. doi: 10.1016/0378-4290(91)90031-P

Shaw, R. G., Byers, D. L., and Darmo, E. (2000). Spontaneous mutational effects on reproductive traits of Arabidopsis thaliana. Genetics 155, 369-378. doi: 10.1093/ genetics/155.1.369

Sher, A., Khan, A., Ashraf, U., Liu, H. H., and Li, J. C. (2018). Characterization of the effect of increased plant density on canopy morphology and stalk lodging risk. Front. Plant Sci. 9:1047. doi: 10.3389/fpls.2018.01047

Simmonds, N. W. (1996). Yields of cereal grain and protein. Exp. Agric. 32, 351-356. doi: 10.1017/S0014479700026284

Sinapidou, E., Pankou, C., Gekas, F., Sistanis, I., Tzantarmas, C., Tokamani, M., et al. (2020). Plant yield efficiency by homeostasis as selection tool at ultralow density. A comparative study with common stability measures in maize. Agronomy 10:1203. doi: 10.3390/agronomy10081203

Solomon, K. F., Chauhan, Y., and Zeppa, A. (2017). Risks of yield loss due to variation in optimum density for different maize genotypes under variable environmental conditions. J. Agron. Crop Sci. 203, 519-527. doi: 10.1111/jac. 12213

Sprague, G. F., Russell, W. A., and Penny, L. H. (1960). Mutations affecting quantitative traits in selfed progeny of doubled monoploid maize stocks. Genetics 45, 855-865. doi: 10.1093/genetics/45.7.855

Thomason, W. E., Brooks, W. S., Griffey, C. A., and Vaughn, M. E. (2009). Hulless barley seeding rate effects on grain yield and yield components. Crop Sci. 49, 342-346. doi: $10.2135 /$ cropsci2008.03.0174

Tokatlidis, I. (2014). Addressing the yield by density interaction is a prerequisite to bridge the yield gap of rain-fed wheat. Ann. Appl. Biol. 165, 27-42. doi: 10.1111/aab.12121

Tokatlidis, I. S. (2015). Conservation breeding of elite cultivars. Crop Sci. 55, 2417-2434. doi: 10.2135/cropsci2015.04.0220

Tokatlidis, I. S. (2017). Crop adaptation to density to optimise grain yield: breeding implications. Euphytica 213:92. doi: 10.1007/s10681-017-1874-8
Tokatlidis, I. S., Has, V., Mylonas, I., Has, I., Evgenidis, G., Melidis, V., et al. (2010). Density effects on environmental variance and expected response to selection in maize (Zea mays L.). Euphytica 174, 283-291. doi: 10.1007/s10681-010-0160-9

Tokatlidis, I. S., and Koutroubas, S. D. (2004). A review of maize hybrids' dependence on high plant populations and its implications for crop yield stability. Field Crops Res. 88, 103-114. doi: 10.1016/j.fcr.2003.11.013

Tokatlidis, I. S., Koutsika-Sotiriou, M., and Fasoulas, A. C. (2001). The development of density independent maize hybrids. Maydica 46, 21-25.

Tollenaar, M., Deen, W., Echarte, L., and Liu, W. (2006). Effect of crowding stress on dry matter accumulation and harvest index in maize. Agron. J. 98, 930-937. doi: 10.2134/agronj2005.0336

Tollenaar, M., and Lee, E. A. (2002). Yield potential, yield stability, and stress tolerance in maize. Field Crops Res. 75, 161-169. doi: 10.1016/S0378-4290(02) 00024-2

Trenberth, K. E. (2011). Changes in precipitation with climate change. Clim. Res. 47, 123-138. doi: 10.3354/cr00953

Weiner, J., and Damgaard, C. (2006). Size-asymmetric competition and sizeasymmetric growth in a spatially explicit zone-of-influence model of plant competition. Ecol. Res. 21, 707-712. doi: 10.1007/s11284-006-0178-6

Whan, A. P., Smith, A. B., Cavanagh, C. R., Ral, J. P. F., Shaw, L. M., Howitt, C. A., et al. (2014). GrainScan: a low cost, fast method for grain size and colour measurements. Plant Methods 10:23. doi: 10.1186/1746-4811-10-23

Yan, P., Pan, J., Zhang, W., Shi, J., Chen, X., and Cui, Z. (2017). A high plant density reduces the ability of maize to use soil nitrogen. PLoS One 12:e0172717. doi: 10.1371 /journal.pone.0172717

Conflict of Interest: The authors declare that the research was conducted in the absence of any commercial or financial relationships that could be construed as a potential conflict of interest.

The reviewer IM declared a past co-authorship with one of the authors AT to the handling editor.

Publisher's Note: All claims expressed in this article are solely those of the authors and do not necessarily represent those of their affiliated organizations, or those of the publisher, the editors and the reviewers. Any product that may be evaluated in this article, or claim that may be made by its manufacturer, is not guaranteed or endorsed by the publisher.

Copyright (c) 2022 Tsivelikas, Ben Ghanem, El-Baouchi and Kehel. This is an openaccess article distributed under the terms of the Creative Commons Attribution License (CC BY). The use, distribution or reproduction in other forums is permitted, provided the original author(s) and the copyright owner(s) are credited and that the original publication in this journal is cited, in accordance with accepted academic practice. No use, distribution or reproduction is permitted which does not comply with these terms. 